\title{
MANAJEMEN KURIKULUM DAN PEMBELAJARAN DALAM SISTEM PENDIDIKAN NASIONAL
}

\author{
Mahrus \\ STAI Nahdlatul Ulama Malang \\ mahrus283@gmail.com
}

DOI: 10.35719/jieman.v3i1.59

\begin{abstract}
Abstrak
Kurikulum dan pembelajaran memiliki posisi penting dalam sistem pendidikan nasional. Kuriklum sebagai program pendidikan (ideal curriulum) menekankan pada proses pembelajaran operasional. Sebagai alat yang penting dalam rangka mencapai tujuan pendidikan, kurikulum dan pembelajaran hendaknya adaptif terhadap perubahan zaman dan kemajuan ilmu pengetahuan dan teknologi. Dalam implementasi kurikulum dan pembelajaran diperlukan manajemen efektif dan efisien, sehingga menjaga kedaulatan sistem pendidikan nasional dalam rangka menjaga nilai-nilai kebangsaan dan untuk mencapai tujuan pendidikan nasional seperti yang telah dicita-citakan para pendiri bangsa. Penelitian ini berdasarkan pemikiran bahwa manajemen kurikulum dan pembelajaran menjadi komponen penting dalam sistem pendidikan nasional yang saling terkait secara terpadu untuk mencapai tujuan pendidikan nasional. Metode yang digunakan dalam penelitian ini adalah metode deskriptif dengan pendekatan kualitatif. Teknik yang digunakan dalam mengumpulkan data adalah studi pustaka yaitu menelaah buku, literatur dan catatan. Analisis data dilakukan dengan kategorisasi dan penafsiran data. Manajemen kurikulum dan pembelajaran dalam sistem pendidikan nasional merupakan suatu proses yang sangat komplek dan melibatkan berbagai komponen yang saling terkait dalam rangka mengarahkan segala bentuk aktivitas pendidikan untuk mencapai tujuan pendidikan nasional. Prosedur manajemen kurikulum terdiri dari perencaaan kurikulum dan pembelajaran, pengorganisasian manajemen
\end{abstract}


JIEMAN: Journal of Islamic Educational Management

kurikulum dan pembelajaran, pelaksanaan manajemen kurikulum dan pembelajaran, serta evaluasi manajemen kurikulum dan pembelajaran.

Kata Kunci: manajemen kurikulum dan pembelajaran, sistem pendidikan nasional

\begin{abstract}
Curriculum and learning process have an important role in the national education system. Curriculum seen an educational program (ideal curriculum), emphasizes the operational learning process. As it is considered to be an important instrument to achieve educational objectives, curriculum and learning should be adaptive towards the constantly changing times and advances in science and technology. Effective and efficient management is needed in implementing the curriculum and learning themselves to maintain the national education system's autonomous nature and the national values, as well as achieving the national education objectives as sought by the founding fathers of the nation. This research is based on the idea that curriculum and learning management are important components to look at in the national education system that are interrelated in an integrated manner to achieve national education objectives. The method used in this study is a descriptive method with a qualitative approach. Literature study such as reviewing books, literature and notes was used to collect the data. Meanwhile, data analysis was carried out by categorizing and interpreting the collected data. Curriculum and learning management in the national education system is considered to be a very complex process which involves various interrelated components to direct all forms of educational activity to achieve national education objectives. The curriculum management procedures consist of planning, organizing, implementing, and evaluating the aspect of curriculum and learning themselves.
\end{abstract}

Keywords: curriculum and learning management, national education system

\title{
Pendahuluan
}

Pendidikan merupakan faktor penting dalam menentukan kualitas manusia yang dimiliki suatu bangsa. Salah satu cara 
menilai pendidikan adalah dengan melihat sistem pendidikan yang diterapkan. Sistem pendidikan adalah komponen pendidikan yang dianggap mampu menentukan kualitas manusia ke depannya. Sistem pendidikan yang diterapkan pemerintah Indonesia adalah berfokus pada pendidikan karakter dengan dilakukannya penilaian dalam semua bidang mata pelajaran yang diampu siswa.

Kurikulum dan pembelajaran mempunyai kedudukan sentral dalam seluruh proses pendidikan. Kurikulum dan pembelajaran mengarahkan segala bentuk aktivitas pendidikan demi tercapainya tujuan-tujuan pendidikan. Kurikulum merupakan suatu rencana pendidikan, memberikan pedoman dan pegangan tentang jenis lingkup, dan urutan isi, serta proses pendidikan.

Dalam perjalanan sejarah dari tahun 1945 hingga 2020 negara kita memiliki 10 kurikulum pendidikan nasional yang telah mengalami perubahan, yaitu pada tahun 1947, 1952, 1964, 1968, 1975, 1984, 1994, 2004, 2006 dan 2013. Adapun perubahan itu dipengaruhi oleh situasi politik, sosial budaya, ekonomi dan pertimbangan lainnya. Namun dari semua perubahan tersebut, kurikulum pendidikan nasional dirangcang berdasarkan landasan yang sama yaitu Pancasila dan Undang-Undang Dasar Negara Republik Indonesia Tahun 1945.

Sebagai negara yang besar dari segi geografis, suku bangsa, potensi ekonomi dan beragamnya kemajuan pembagunan dari satu daerah ke daerah lain, sekecil apapun disinegrasi bangsa masih tetap ada, maka kurikulum harus bisa membentuk manusia Indonesia yang mampu meyeimbangkan kebutuhan individu dan masyarakat untuk memajukan jati dirinya. Selain itu kurikulum dan pembelajaran juga harus mempertimbangkan, merespon dan berlandaskan pada perkembangan social budaya dalam suatu masyarakat, baik dalam konteks local, nasional maupun global. Namun seperti yang kita ketahui saat ini, sosial budaya selalu mengalami perubahan baik itu secara cepat atau lambat. Hal lain yang penting adalah peserta didik, yang berasal dari masyarakat, mendapatkan pendidikan baik formal maupun informal dalam 
lingkungan masyarakat dadiarahkan bagi kehidupan masyarakat pula.

Kurikulum di Indonesia sering sekali mengalami perubahan. Namun, perubahan tersebut hanyalah sebatas perubahan nama semata. Tanpa mengubah esensi kurikulum, tentulah tidak akan ada dampak positif dari perubahan kurikulum Indonesia. Pengembangan suatu kurikulum tentu saja berdasarkan sumber prinsip, untuk menunjukan dari mana asal mula lahirnya suatu prinsip pengembangan kurikulum. Sumber prinsip pengembangan kurikulum yang dimaksud adalah data empiris (pengalaman yang terdokumentasi dan terbukti efektif), data eksperimen (temuan hasil penelitian), cerita/legenda yang hidup di masayaraksat (folklore of curriculum), dan akal sehat (common sense). ${ }^{1}$

\section{Pembahasan}

\section{Konsep Dasar Manajemen Kurikulum dan Pembelajaran}

Menurut Undang-Undang Nomor 20 Tahun 2003 tentang Sistem Pendidikan Nasional, kurikulum adalah seperangkat rencana dan pengaturan mengenai tujuan, isi dan bahan pelajaran, serta cara yang digunakan sebagai pedoman penyelenggaraan kegiatan pembelajaran untuk mencapai tujuan pendidikan tertent. Tujuan tersebut meliputi tujuan pendidikan nasional, kesesuaian dengan kekhasan, kondisi dan potensi daerga, satuan pendidikan, dan peserta didik.

Departemen Pendidikan Nasional menyatakan bahwa kurikulum merupakan seperangkat rencana dan pengaturan tentang kompetensi yang dibakukan dan cara pencapaiannya disesuaikan dengan keadaan dan kemampuan. Kurikulum dilaksanakan dalam rangka membantu peserta didik mengembangkan berbagai potensi baik psikis dan fisik yang meliputi moral dan nilai-

${ }^{1}$ Suharsimi Arikunto dan L Yuliana. Manajemen Pendidikan, (Yogyakarta: Aditya Media, 2010). 
nilai agama, social emosional, kognitif, bahasa, fisik/motorik, kemandirian dan seni. ${ }^{2}$

Kurikulum dapat dilihat dari tiga dimensi, yaitu sebagai ilmu (curriculum as a body of knowledge) sebagai sistem (curriculum as a system) dan sebagai rencana (curriculum as a plan). Krukulum sebagai ilmu mengkaji konsep. Landasan, asumsi, teori, model, praksis dan prinsip-prinsip dasar tentang kurikulum. Kurikulum sebagai sistem menjelaskan kedudukan kurikulum dalam hubungannya dengan sistem dan bidang-bidang lain, komponenkomponen kurikulum, kurikulum berbagai jalur, jenjang, jenis pendidikan dan manajemen kurikulum. Kurikulum sebagai rencana mencakup macam-macam rencana atau desain kurikulum, sedangkan kurikulum sebagai rencana ada yang bersifat menyeluruh untuk semua jalur, jenjang dan semua jenis pendidikan, ada pula yang bersifat khusus untuk jalur, jenjang dan jenis pendidikan tertentu. ${ }^{3}$

Manajemen kurikulum dan pemebalajaran berkenaan dengan bagaimana kurikulum dan pembelajaran dirancang, dilaksanakan, dan dikendalikan (dievaluasi dan disempurnakan), oleh siapa, kapan dan dalam lingkup mana. Manajemen kurikulum juga berkaitan dengan siapa yang diberi tugas, wewenang dan tanggungjawab dalam merancang, melaksa-nakan dan mengendalikan kurikulum. Secara umum, menajamen pengembangaan dibedakan antara manajemen kurikulum terpusat (centralized curriculum development management atau top down curriculum development) dan manajemen pengembangan kuriku-lum tersebar (decentralized curriculum development management atau bottom up curriculum development). ${ }^{4}$

2 Kementerian Pendidikan Nasional. Manajemen Berbasis Sekolah. (Jakarta: Pusat Pengembangan Tenaga Kepenendidikan, 2012)

3 Hery Widyastono, "Implikasi RPJMN 2010-2014 Sektor Pendidikan terhadap Manajemen Pengembangan Kurikulum Pendidikan Dasar dan Menengah” Diunduh dari : http://litbang.kemdikbud.go.id/jurnaldukbud/index.php/jpnk/

${ }^{4}$ Wina Sanjaya, Perencanaan dan Desain Sistem Pembelajaran (Jakarta: Kencana Prenada Media Group, 2008), 90; Lihat juga Oemar Hamalik, Dasardasar Pengembangan Kurikulum, (Bandung: Remaja Rosdakarya, 2007). 
Kurikulum sebagai sistem memiliki komponen-komponen yang saling terkait. Kurikulum memiliki empat komponen, yaitu komponen tujuan, isi kurikulum, metode atau strategi penccapaian tujuan dan komponen evaluasi. Sebagai suatu sistem, setiap komponen berkaitan satu sama lain. Manakala salah satu komponen yang membentuk sistem kurikulum terganggu atau tidak berkaitan dengan komponen lainnya, sistem kurikulum juga akan tergangggu.

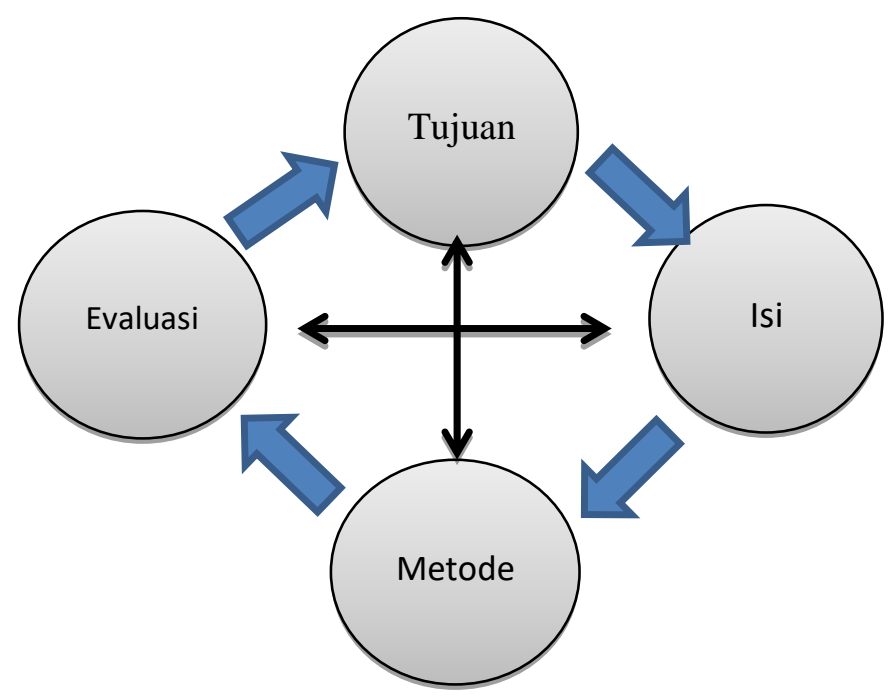

Gambar 1. Sistem Kurikulum ${ }^{5}$

Mengurai manajemen pembelajaran harus dimulai dari pengertian belajar dan pembelajaran. Belajar adalah proses perubahan tingkah laku individu yang relatif tetap sebagai hasil dari pengalaman, sedangkan pembelajaran merupakan upaya penataan lingkungan yang memberi nuansa agar program belajar tumbuh berkembang secara optimal. Proses belajar bersifat internal dan unik dalam diri individu siswa, sedangkan proses pembelajaran

${ }^{5}$ Permendikbud 81 A Tahun 2013 Tentang Implementasi Kurikulum. 
bersifat eksternal yang sengaja direncanakan dan bersifat rekayasa perilaku. Ada dua faktor yang mempengaruhi keberhasilan pembelajaran, yaitu faktor yang berasal dari dalam individu yang sedang belajar, dan faktor yang berasal dari luar individu. Faktor yang terdapat di dalam individu dikelompokkan menjadi dua faktor, yaitu faktor psikis dan faktor fisik. Kedua faktor tersebut keberadaannya ada yang ditentukan oleh faktor keturunan, ada yang ditentukan oleh faktor lingkungan, da nada pula yang ditentukan oleh faktor keturunan dan lingkungan. Sementara itu, faktor yang berasal dari luar individu dikelompokkan menjadi faktor lingkungan alam, sosial-ekonomi, guru, metode mengajar, kurikulum, program, metode pelajaran, serta sarana dan prasarana. ${ }^{6}$

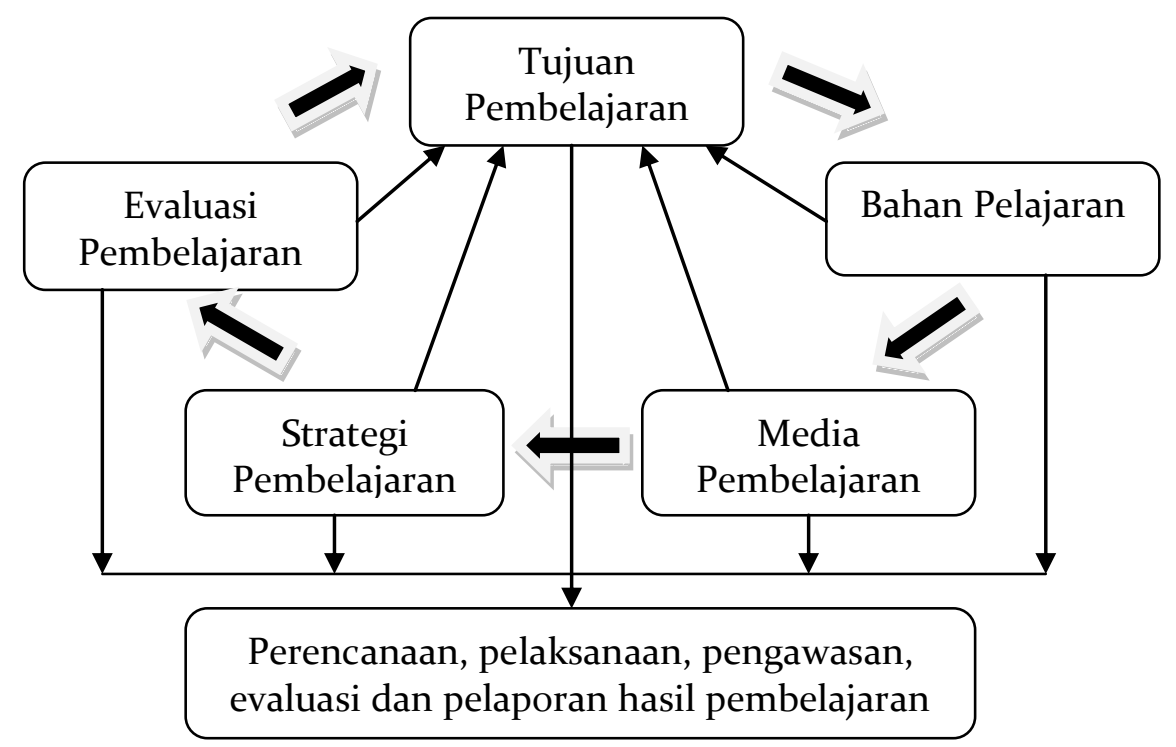

Gambar 2. Siklus Manajemen Pembelajaran ${ }^{7}$

Berdasarkan uraian di atas dapat disimpulkan bahwa manajemen pembelajaran adalah pemanfaatan sumber daya

${ }^{6}$ Teguh Triwiyanto, Manajemen Kurikulum dan Pembelajaran, (Jakarta: Bumi Aksara, 2013). 21

${ }^{7}$ Permendikbud 81 A Tahun 2013 Tentang Implementasi Kurikulum 
pembelajaran yang ada, baik faktor yang berasal dari individu yang sedang belajar maupun faktor yang berasal dari luar individu untuk mencapai tujuan pendidikan yang efektif dan efisien. Manajemen pembelajaran meliputi aktivitas-aktivitas perencanaan, pelaksanaan, pengawasan, evaluasi dan pelaporan hasil pembelajaran sebagaimana Gambar 2.

\section{Hubungan antara Kurikulum dan Pembelajaran}

Pelaksanaan kurikulum tidak akan pernah terlepas dari kegiatan pembelajaran karena kurikulum merupakan usaha untuk mensukseskan tujuan pendidikan. Diperlukan pengelolaan, penataan, dan pengaturan ataupun kegiatan yang sejenis yang masih berkaitan dengan pendidikan guna mengembangkan sumber daya manusia agar dapat memenuhi tujuan pendidikan seoptimal mungkin. Artinya, pembelajaran tanpa kurikulum sebagai rencana tidak akan efektif, atau bahkan bisa keluar dari tujuan yang telah dirumuskan. Kurikulum tanpa pembelajaran, maka kurikulum tersebut tidak akan berguna.

Kurikulum merupakan rencana tertulis yang berisi tentang ide-ide dan gagasan-gagasan yang dirumuskan oleh pengembang kurikulum. Rencana tertulis itu kemudian menjadi dokumen kurikulum yang membentuk suatu sistem kurikulum yang terdiri dari komponen-komponen yang saling mempengaruhi satu sama lain, seperti misalnya komponen tujuan yang menjadi arah tujuan dan komponen evaluasi. Komponen-komponen yang membentuk sistem kurikulum selanjutnya melahirkan sistem pembelajaran, dan sistem pembelajaran itulah yang menjadi pedoman guru dalam pengelolaan proses belajar mengajar di dalam kelas. Dengan demikian maka dapat dikatakan sistem pembelajaran merupakan pengembangan dari sistem kurikulum yang digunakan. ${ }^{8}$

Dalam kegiatan proses pembelajaran, kurikulum sangat dibutuhkan sebagai pedoman untuk menyusun target dalam proses belajar mengajar. Namun, dalam memahami hakikat kurikulum

${ }^{8}$ Wina Sanjaya, Perencanaan dan Desain Sistem Pembelajaran (Jakarta: Kencana Prenada Media Group, 2008), 78. 
sering terjadi perbedaan persepsi dan pemahaman. Kurikulum dipandang sebagai suatu bahan tertulis yang berisi uraian tentang program pendidikan suatu sekolah yang harus dilaksanakan dari tahun ke tahun. Oleh karena itu, dapat juga dikatakan bahwa tindakan-tindakan itu pada dasarnya implementasi dari kurikulum, yang selanjutnya implementasi itu akan memberikan masukan dalam proses perbaikan kurikulum. Demikian terus menerus, sehingga proses pengembangan kurikulum membentuk siklus yang tanpa ujung. ${ }^{9}$

Hubungan kurikulum dan pembelajaran dalam tercapainya tujuan pendidikan dilukiskan dengan kurikulum sebagai program pendidikan yang direncanakan dan dilaksanakan untuk mencapai tujuan yang mencakup seluruh pengalaman belajar yang diorganisasikan dan dikembangkan dengan baik serta disiapkan bagi murid untuk mengatasi situasi kehidupan yang sebenarnya. Sementara itu, pengertian lainnya ditafsirkan secara sempit yang hanya menekankan kepada kemanfaatannya dalam merencanakan tujuan pembelajaran, pengalaman-pengalaman belajar dan pembela-jaran, alat-alat pelajaran dan cara-cara penilaian yang direncanakan dan digunakan dalam kegiatan belajar dan pembelajaran. $^{10}$

Kurikulum dan pembelajaran merupakan dua hal yang tidak dapat dipisahkan walaupun keduanya memiliki posisi yang berbeda. Kurikulum berfungsi sebagai pedoman yang memberikan arah dan tujuan pendidikan, serta isi yang harus dipelajari, sedangkan pembelajaran adalah proses yang terjadi dalam interaksi belajar dan mengajar antara guru dan murid. Hubungan kurikulum dan pembelajaran ini diungkapkan Saylor dalam Rusman:" "The terms curriculum and instruction are interlocked almost as

${ }^{9}$ Aldo Redo Syam. Posisi Manajemen Kurikulum dan Pembelajaran dalam $\begin{array}{llllll}\text { Pendidikan. } & \text { Jurnal } & \text { Muaddib: } & \text { Vol } & 7 . & 2017 .\end{array}$ http://www.researchgate.net/publication/318676341.

${ }^{10}$ Sholeh Hidayat, Pengembangan Kurikulum Baru (Bandung: Remaja Rosdakarya, 2013). 27

${ }^{11}$ Rusman, Manajemen Kurikulum, (Jakarta: Rajawali Pres, 2012), 84. 
inextricable as name Tristan and Isoled or Romeo and Juliet. Without a curriculum or plan, there can be no effective instruction and without instruction the curriculum has little meaning".

Walaupun antara kurikulum dan pembelajaran merupakan dua sisi yang tidak dapat dipisahkan, namun dalam proses pembelajaran dapat terjadi berbagai kemungkinan hubungan anatara keduanya. Peter F. Oliva sebagaimana dikutip Sanjaya $^{12}$ menggambarkan kemungkinan hubungan antara kurikulum dengan pengajaran dalam beberapa model sebagai berikut:

1. Model Dualistis (The Dualistic Model). Pada model ini kurikulum dan pembelajaran terpisah. Keduanya tidak bertemu. Kurikulum yang seharusnya menjadi imput dalam menata sistem pengajaran tidak tampak. Demikian juga pembelajaran yang semestinya memberikan balikan dalam proses penyempurnaan kurikulum tidak terjadi, karena kurikulum dan pembelajaran berjalan sendiri. Model ini digambarkan sebagai berikut:
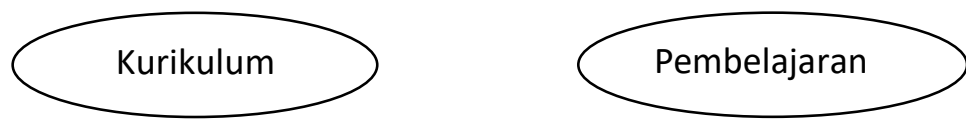

Gambar 3 Model Dualistis

2. Model Berkaitan (The Interlocking Model). Dalam model ini kurikulum dan pembelajaran dianggap sebagai suatu sistem yang keduanya memiliki hubungan. Kurikulum dan pembelajaran maupun sebaliknya pembelajaran dan kurikulum ada bagian yang berkaitan, sehingga keduanya memiliki hubungan. Digambarkan sebagai berikut:

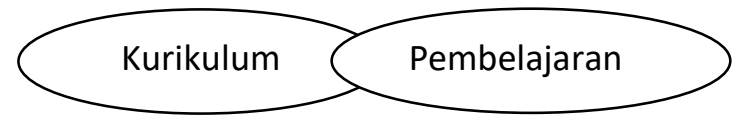

Gambar 4 Model Berkaitan

\footnotetext{
${ }^{12}$ Sanjaya, Perencanaan..., 20-22.
} 
3. Model Konsentris (The Concentric Model). Pada model ini kurikulum dan pembelajaran memiliki hubungan dengan kemungkinan kurikulum bagian dari pembelajaran atau pembelajaran bagian dari kurikulum. Di sini ada ketergantungan satu dengan yang lain. Model konsentris ini digambarkan sebagai berikut:
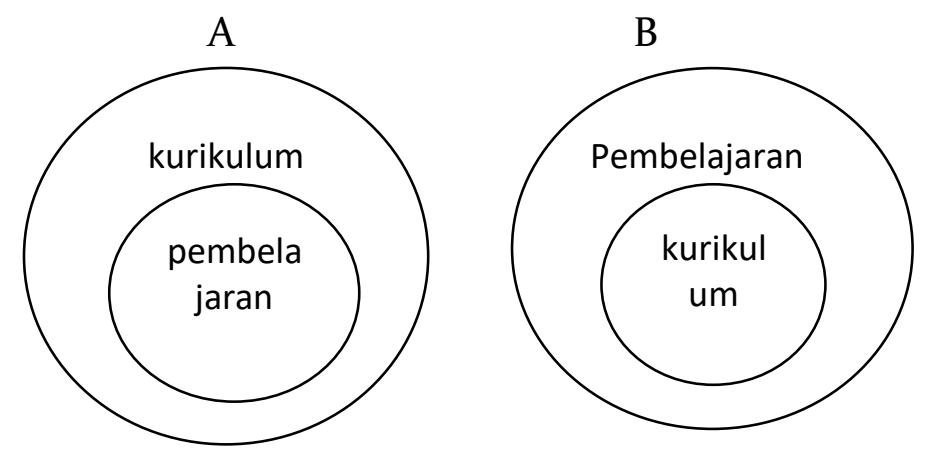

Gambar 5. Model Konsentris

4. Model Siklus (The Ciclical Model). Model ini menggambarkan hubungan timbal balik antara kurikulum dan pembelajaran. Keduanya dianggap saling mempengaruhi. Segala yang ditentukan dalam kurikulum akan menjadi dasar dalam proses pelaksanaan pembelajaran. Sebaliknya yang terjadi dalam pengajaran dapat memengaruhi keputusan kurikulum selanjutnya. Dalam model ini hubungan keduanya sangat erat meski kedudukannya terpisah yang berarti dalam analisis juga terpisah. Digambarkan sebagai berikut

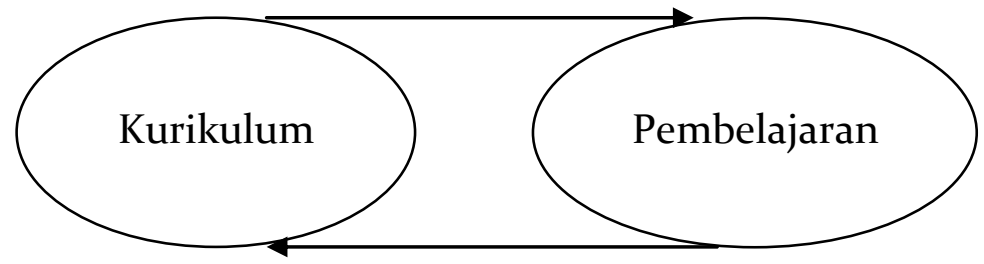

Gambar 6 Model Siklus 
Dari beberapa penjelasan di atas, dapat dipahami bahwa kurikulum dan pembelajaran memiliki hubungan yang sangat erat, dengan kurikulum sebagai bahan tertulis atau program pendidikan dengan lebih menekankan pada operasional proses pembelajaran. Kurikulum berhubungan dengan isi ataupun materi yang harus dipelajari sedangkan pembelajaran berkaitan dengan bagaimana cara mempelajarinya. Tanpa kurikulum sebagai rencana, maka pembelajaran tidak akan efektif, demikian juga sebaliknya tanpa pembelajaran sebagai implementasi sebuah rencana, maka kurikulum tidak akan memiliki arti apa-apa

\section{Perencaan Kurikulum dan Pembelajaran}

1. Perencanaan Kurikulum

Pusat Kurikulum menyatakan bahwa kurikulum sebagai sebuah rencana merupakan dimensi kurikulum yang paling banyak dikenal dan diketehui publik, baik oleh para pelaksana kurikulum (guru dan pimpinan satuan pendidikan) maupun masyarakat terutama orang tua. Kurikulum sebagai rencana ( $a$ plan of action) atau disebut juga keurikulum tertulis (written curriculum) atau kurikulum sebagai dokumen (document curriculum) menjadi acuan atau pengangan bagi guru-guru dan para pelaksana kurikulum lainnya dalam implementasi kurikulum. Sebagai suatu acuan atau pedoman, kurikulum berbentu dokumen tertulis juga disebut sebagai kurikulum formal (formal curriculum) atau kurikulum lembaga (official curriculum). ${ }^{13}$

Pengertian perencanaan kurikulum adalah perencanaan kesempatan-kesempatan belajar yang dimaksudkan untuk membina kea rah perubahan tingkah laku yang diinginkan dan menilai sampai mana perubahan-perubahan telah terjadi pada siswa. Perubahan tingkah laku yang dimaksud adalah perubahan kea rah yang baik. Perilaku berdasar pada proposisi bahwa semua yang dilakukan organisme termasuk tindakan,

13 Pusat Kurikulum, Kurikulum Tingkat Satuan Pendidikan (Jakarta: Departemen Pendidikan Nasional, 2007). 
pikiran, atau perasaan dapat dan harus dianggap sebagai perilaku. Perilaku demikian dapat digambarkan secara ilmiah tanpa melihat peristiwa fisiologis internal atau konstruk hipotesis seperti pikiran.

2. Perencanaan Pembelajaran

Perencanaan pembelajaran adalah seperangkat rencana dan pengaturan kegiatan pembelajaran, media pembelajaran, waktu, pengelolaan kelas, dan penilaian hasil belajar. Tujuan perencanaan pembelajaran adalah memberikan panduan dalam menyusun dan melaksanakan pembelajaran dan sebagai bahan evaluasi dan control dalam penyusunan program pembelajaran. Dalam perencanaan pembelajaran terdapat kompetensi yang akan dikembangkan, cara mengembangkan kompetensi dan cara mengetahui penguasaan peserta didik terhadap kompetensi. ${ }^{14}$

Fungsi perencaan pembelajaran adalah sebagai panduan atau pedoman dalam penyusunan program pembelajaran, penyiapan proses pembelajaran, penyiapan bahan/media/ sumber belajar dan penyiapan perangkat penilaian. Sedangkan manfaat perencanaan pembelajaran dalah untuk memudahkan pembuatan persiapan pembelajaran dan memudahkan mengembangkan pembelajaran yang aktif, kreatif, efektif dan menyenangkan. Perencanaan pembelajaran dalam kurikulum biasa disebut dengan Rencana Pelaksanaan Pembelajaran (RPP), yaitu rencana pembelajaran yang dikembangkan secara rinci dari suatu materi pokok atau tema tertentu yang mengacu pada silabus. RPP mencakup : (a) Data sekolah, mata pelajaran, dan kelas/semester, (b) Materi pokok, (c) Alokasi waktu, (d) Tujuan pembelajaran, Kompetensi Dasar (KD) dan indikator pencapaian kompetensi, (e) Materi dan metode pembelajaran, (f) Media, alat dan sumber belajar, (g) langkah-langkah kegiatan pembelajaran, dan (h) Penilaian.

${ }^{14}$ Nasbi Ibrahim. Manajemen Kurikulum Sebuah Kajian Teoritis. Jurnal Idaroh. Vol 1 No 22017. 
3. Tujuan Perencaan Kurikulum dan Pembelajaran

a. Sebagai pedoman penyelenggaraan kegiatan pembelajaran untuk mencapai tujuan pendidikan tertentu.

b. Standar pengawasan dalam pelaksanaan kurikulum, yaitu mencocokkan perencanaanya dan pelaksanaannya.

c. Mengetahui siapa yang terlibat (struktur organisasinya), baik kualifikasinya maupun kuantitasnya untuk mencapai tujuan pendidikan.

d. Merupakan gambaran kurikulum yang sistematis termasuk biaya dan kualitas pekerjaan.

e. Meminimalkan kegiatan-kegiatan yang tidak produktif, serta menghemat tenaga, biaya dan waktu. ${ }^{15}$

4. Landasan Perencaan Kurikulum dan Pembelajaran

Perencanaan kurikulum harus mengasimilasi dan mengorganisasi informasi dan data secara intensif yang berhubungan dengan pengembangan program lembaga atau sekolah. Informasi dan data yang menajadi daerah utama adalah kekuatan sosial, perlakuan pengetahuan, serta pertumbuhan dan perkembangan manusia.

Kekuatan sosial merujuk pada penyesuaian perencanaan kurikulum dengan perubahan dan dinamika sosial yang terjadi di masyarakat seperti sistem politik, ekonomi, social, dan kebudayaan. Perilaku pengetahuan merujuk pada pertumbuhan dan perkembangan pengetahuan, serta perilaku individu belajar aktif untuk mengumpulkan dan mengelola informasi, mencari fakta dan data, berusaha belajar tentang sikap, emosi, perasaan terhadap pembelajaran, proses informasi, memanipulasi, menyimpan dan mengambil kembali informasi tersebut untuk dikembangkan dan digunakan dalam kegiatan merancang kurikulum yang disesuaikan dengan perkembangan ilmu.

Perencanaan kurikulum dan pembelajaran juga tidak boleh meninggalkan aspek-aspek yang memberikan pengaruh dalam tercapainya tujuan pendidikan. Aspek-aspek tersebut

${ }^{15}$ Teguh Triwiyanto, Manajemen Kurikulum dan Pembelajaran, (Jakarta: Bumi AKsara, 2015). 103 
antara lain perlakuan akses, standar nasional pendidikan, standar layanan minimal, perbaikan sarana dan prasarana, beasiswa peserta didik miskin, dan dekonsentrasi dana pendidikan.

\section{Pengorganisasian Kurikulum dan Pembelajaran}

Pengorganisasian kurikulum dan pembelajaran merupakan proses menyusun organisasi kurikulum dan pembelajaran secara formal dengan aktivitas merancang struktur, menganalisis beban materi pelajaran, menganalisis kualifikasi materi pelajaran, mengelompokkan dan membagikan beban materi pelajaran pada tiap-tiap jalur, jenjang dan jenis pendidikan. Tiga aspek yang harus diperhatikan dalam pengorganisasian kurikulum antara lain: (a) pemerincian materi pelajaran, yaitu menentukan beban dan jenis materi untuk mencapai tujuan pendidikan, (b) pembagian materi pelajaran berdasarkan jalur, jenjang dan jenis pendidikan, dan (c) pengembangan mekanisme hubungan antara materi pelajaran berdasarkan jalur, jenjang dan jenis pendidikan.

1. Tujuan Pengorganisasian Kurikulum dan Pembelajaran

Tujuan pengorganisasian kurikulum dan pembelajaran dapat ditinjau dari struktur kurikulum dan pembelajaran. Melalui pengorganisasian kurikulum dan pembelajaran tujuan pendidikan akan terbantu melalui penyesuaian-penyesuaian agar pencapaian tujuan pendidikan lebih mudah dilakukan.

Dalam pengorganisasian kurikulum dan pembelajaran dikenal dengan adanya herarki yang memperlihatkan gradasi pada setiap level. Terdapat lima level dalam herarki tersebut, yaitu (1) tujuan pendidikan nasional, (2) tujuan institusional, (3) tujuan kurikuler, (4) tujuan pembelajaran umum, (5) tujuan pembelajaran khusus. ${ }^{16}$

2. Prinsip-prinpsi Pengorganisasian Kurikulum dan Pembelajaran

Dalam pengorganisasian kurikulum dan pembelajaran harus mempertimbangkan ruang lingkup (scope), urutan bahan (sequence), kontinuitas, keseimbangan, dan keterpaduan

${ }^{16}$ Permendikbud 81 A Tahun 2013 Tentang Implementasi Kurikulum 
(integrated). ${ }^{17}$ Selain itu juga dibutuhkan prinsip fleksibilitas dalam pengorganisasian kurikulum dan pembelajaran, yaitu bahwa dalam pengorganisasian tetap memperhatikan perbedaan kemampuan, minat dan kebutuhan peserta didik dan pengguna. Fleksibilitas menunjukkan bahwa pengorganisasian kurikulum tetap harus memperhatikan karakteristik khas peserta didik.

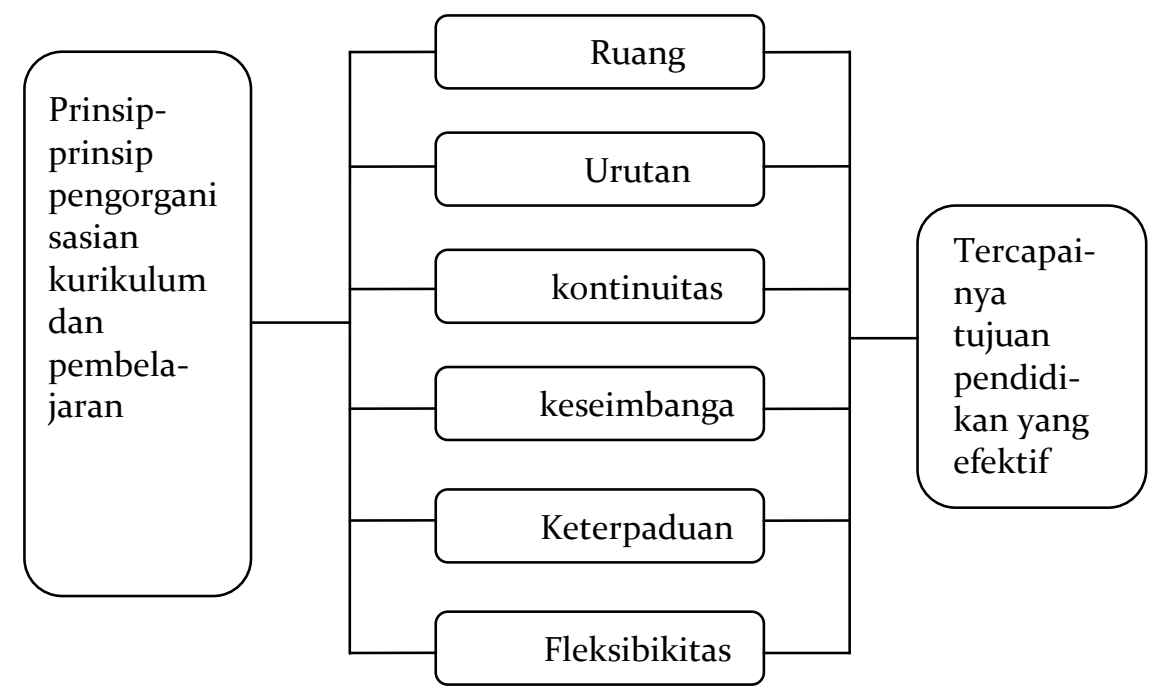

Gambar 8. Hubungan Prinsip-prinsip Pengorganisasian dengan Pencapaian Tujuan Pendidikan ${ }^{18}$

Ruang lingkup (scope) berarti perlu memperhatikan ciri khas keilmuan dari tiap-tiap mata pelajaran. Ciri khas yang dimaksud adalah ilmu memilikikeluasan dan kedalaman yang dapat dipelajari dengan berdasarkan diri pada jenjang dan tingkat sekolah. Urutan bahan (sequence) berarti adanya saling keterkaitan materi yang harus dipahami antara materi yang didahulukan dan materi yang belakangan. Urutan bahan biasanya berawal dari materi-materi dasar dan beranjak pada materi-materi kompleks, dari yang nyata sampai dengan

${ }^{17}$ Rusman, Manajemen Kurikulum (Jakarta: Rajawali Pres, 2012), 84.

${ }^{18}$ Permendikbud 81 A Tahun 2013 tentang Implementasi Kurikulum 
abstrak. Kontinuitas berarti bahwa bahan materi yang akan dipelajari siswa memiliki keluasan dan kedalaman materi yang sambung menyambung dan tidak terjadi penumpukan materi. Keseimbangan dan keterpaduan berarti bahwa cara dan proses belajar harus seimbang dan padu dengan materi dan kematangan psikologi peserta didik.

Sebagai gambaran dalam pengorganisasian kurikulum dan pembelajaran, table berikut memperlihatkan perbandingan pengorganisasian KTSP 2006 dengan Kurikulum $2013^{19}$

\section{Tabe1 1. Perbandingan Pengorganisasian KTSP 2006 dengan Kurikulum $2013^{20}$}

\begin{tabular}{|l|l|l|}
\hline \multicolumn{1}{|c|}{ KTSP 2oo6 } & \multicolumn{1}{c|}{ Kurikulum 2o13 } & \multicolumn{1}{c|}{ Keterangan } \\
\hline $\begin{array}{l}\text { Mata pelajaran } \\
\text { tertentu mendukung } \\
\text { kompetensi tertentu }\end{array}$ & $\begin{array}{l}\text { Tiap mata pelajaran } \\
\text { mendukung semua } \\
\text { kompetensi (sikap, } \\
\text { pengetahuan dan } \\
\text { keterampilan) }\end{array}$ & Semua jenjang \\
\hline $\begin{array}{l}\text { Mata pelajaran } \\
\text { dirancang berdiri } \\
\text { sendiri dan memiliki } \\
\text { kompetensi dasar } \\
\text { sendiri }\end{array}$ & $\begin{array}{l}\text { Mata pelajaran dirancang } \\
\text { terkait satu dengan yang lain } \\
\text { dan memiliki kompetensi } \\
\text { dasar yang diikat oleh } \\
\text { kompetensi inti tiap kelas }\end{array}$ & Semua jenjang \\
\hline $\begin{array}{l}\text { Bahasa Indonesia } \\
\text { sejajar dengan mata } \\
\text { pelajaran lain }\end{array}$ & $\begin{array}{l}\text { Bahasa Indonesia sebagai } \\
\text { penghela mata pelajaran } \\
\text { yang lain (sikap dan } \\
\text { keterampilan bahasa) }\end{array}$ & SD \\
\hline $\begin{array}{l}\text { Tiap mata pelajaran } \\
\text { diajarkan dengan } \\
\text { pendekatan berbeda }\end{array}$ & $\begin{array}{l}\text { Semua mata pelajaran } \\
\text { diajarkan dengan } \\
\text { pendekatan yang sama } \\
\text { (scientific) melalui } \\
\text { mengamati, menanya, } \\
\text { mencoba, menalar }\end{array}$ & Semua jenjang \\
\hline
\end{tabular}

19 Permendikbud Nomor 57, 58, 59 Tahun 2014 tentang Kompetensi Dasar dan Struktur Kurikulum SD/MI, SMP/MTs, SMA/MA

${ }^{20}$ Permendikbud Nomor 57, 58, 59 Tahun 2014 Tentang Kompetensi Dasar dan Struktur Kurikulum SD/MI, SMP/MTs, SMA/MA 


\begin{tabular}{|c|c|c|}
\hline $\begin{array}{l}\text { Tiap jenis konten } \\
\text { pembelajaran } \\
\text { diajarkan terpisah } \\
\text { (separated curriculum) }\end{array}$ & $\begin{array}{l}\text { Bermacam jenis konten } \\
\text { pembelajaran diajarkan } \\
\text { terkait dan terpadu satu } \\
\text { sama lain (cross curriculum } \\
\text { dan integrated curriculum) } \\
\text { Konten ilmu pengetahuan } \\
\text { diintegrasikan dan dijadikan } \\
\text { penggerak konten } \\
\text { pembelajaran lainnya }\end{array}$ & SD \\
\hline $\begin{array}{l}\text { Tematik untuk kelas I- } \\
\text { III (belum integratif) }\end{array}$ & $\begin{array}{l}\text { Tematik integrative untuk } \\
\text { kelas I-VI }\end{array}$ & SD \\
\hline $\begin{array}{l}\text { TIK adalah mata } \\
\text { pelajaran sendiri }\end{array}$ & $\begin{array}{l}\text { TIK merupakan sarana } \\
\text { pembelajaran, dipergunakan } \\
\text { sebagai media pembelajaran } \\
\text { mata pelajaran lain }\end{array}$ & SMP \\
\hline $\begin{array}{l}\text { Bahasa Indonesia } \\
\text { sebagai pengetahuan }\end{array}$ & $\begin{array}{l}\text { Bahasa Indonesia sebagai } \\
\text { alat komunikasi dan carries } \\
\text { of knowledge }\end{array}$ & SMP/SMA/SMK \\
\hline $\begin{array}{l}\text { Untuk SMA ada } \\
\text { penjurusan sejak kelas } \\
\text { XI }\end{array}$ & $\begin{array}{l}\text { Tidak ada penjurusan di } \\
\text { SMA. Ada mata pelajaran } \\
\text { wajib, peminatan, antar } \\
\text { minat dan pendalaman } \\
\text { minat }\end{array}$ & SMA/SMK \\
\hline $\begin{array}{l}\text { SMA dan SMK tanpa } \\
\text { kesamaan kompetensi }\end{array}$ & $\begin{array}{l}\text { SMA dan SMK memiliki } \\
\text { mata pelajaran wajib yang } \\
\text { sama terkait dasar-dasar } \\
\text { pengetahuan, keterampilan } \\
\text { dan sikap }\end{array}$ & SMA/SMK \\
\hline $\begin{array}{l}\text { Penjurusan di SMK } \\
\text { sangat detail (sampai } \\
\text { keahlian) }\end{array}$ & $\begin{array}{l}\text { Penjurusan di SMK tidak } \\
\text { terlalu detail (sampai bidang } \\
\text { studi) di dalamnya terdapt } \\
\text { pengelompokan peminatan } \\
\text { dan pendalaman }\end{array}$ & SMA/SMK \\
\hline
\end{tabular}

Berdasarkan tabel 1, pengorganisasian dapat dilakukan untuk mata pelajaran, jenjang pendidikan, konten atau isi pelajaran, kompetensi, dan jenis pengorganisasian dari tiap-tipa kurikulum. Pengorganisasian kurikulum dan pembelajaran memberikan petunjuk bahwa pertimbangan ketika melakukan pengembangan kurikulum harus memperhatikan kelebihan dan kekurangan setiap jenisnya. Dengan demikian dapat memini- 
malisasi efek nebatif yang ada atau mungkin ada dalam pelaksanaan kurikulum dan pembelajaran

\section{Pelaksanaan Manajemen Kurikulum dan Pembelajaran}

Pelaksanaan kurikulum dan pembelajaran dalam usaha mencapai tujuan yang sesuai dengan karakteristik, kebutuhan, dan perkembangan daerah dan sekolah, memerlukan pelaksanaan yang terprogram dan sistematis. Institusi yang menangani kurikukum provinsi dan kabupaten/kota dalam melaksanakan tugasnya bekerjasama dengan pusat kurikulum, Lembaga Penjamin Mutu Pendidikan (LPMP), Pusat Pengembangan Penataran Guru (PPPG), Badan Penelitian dan Pengembangan (Balitbang) Kemdikbud, Badan Penelitian dan Pengembangan Daerah (Bappeda), Kementerian Agama, Kantor Wilayah Kementerian Agama, Kantor Wilayah Perwakilan Kementerian Agama, Perguruan Tinggi, Dewan Pendidikan, Organisasi Profesi, Komite Sekolah, Musyawarah Kerja Kepala Sekolah/Madrasah (MKKS/M), Musyawarah Guru Mata Pelajaran (MGMP), KelompokKerja Guru (KKG). ${ }^{21}$

Pelaksanaan kurikulum dan pembelajaran secara sinergis dapat mempercepat dan menghasilkan pencapaian sesuai dengan tujuan pendidikan. Layanan yang diberikan dan aktivitas pelaksanaan dari institusi-institusi di atas dapat dilihat pada table berikut: ${ }^{22}$

Tabel 2. Sinergi Pelaksanaan Kurikulum dan Pembelajaran ${ }^{23}$

\begin{tabular}{|c|c|c|c|}
\hline \multicolumn{1}{|c|}{ Aspek } & \multicolumn{1}{|c|}{$\begin{array}{c}\text { Institusi/ } \\
\text { Layanan }\end{array}$} & \multicolumn{1}{c|}{ Aktivitas Pelaksanaan } \\
\hline $\begin{array}{l}\text { Kurikulum dan } \\
\text { Pembelajaran }\end{array}$ & Ruang lingkup & $\bullet \begin{array}{l}\text { Adanya pertukaran informasi } \\
\text { kurikulum dan pembelajaran }\end{array}$ \\
& & $\begin{array}{l}\text { Adanya pertukaran narasumber } \\
\text { kurikulum dan pembelajaran }\end{array}$ \\
\hline
\end{tabular}

${ }^{21}$ Permendikbud Nomor 58 Tahun 2014 Tentang Kompetensi Dasar dan Struktur Kurikulum SMP/MTs.

${ }^{22}$ Permendikbud 81 A Tahun 2013 Tentang Implementasi Kurikulum.

${ }^{23}$ Pusat Kurikulum, Kurikulum Tingkat Satuan Pendidikan (Jakarta: Departemen Pendidikan Nasional, 2007). 


\begin{tabular}{|c|c|c|}
\hline & & $\begin{array}{ll}\text { - } & \text { Adanya program pemdampingan } \\
\text { kurikulum dan pembelajaran } \\
\text { - } \\
\text { - Adanya kerjasama } \\
\text { Adanya pendampingan pengelolaan } \\
\text { - } \quad \text { Hasil pengembangan kurikulum } \\
\end{array}$ \\
\hline \multirow[t]{7}{*}{$\begin{array}{l}\text { Pelaksana } \\
\text { Program/kegia } \\
\text { tan }\end{array}$} & Bappeda & $\begin{array}{ll}\text { - } & \text { Tingkat fasilitas kegiatan } \\
\text { - } & \text { Memasukkanya sebagian bagian dari } \\
\text { perencanaan pembangunan } \\
\text { pendidikan daerah } \\
\end{array}$ \\
\hline & $\begin{array}{l}\text { Dinas Pendidikan } \\
\text { Kota }\end{array}$ & $\begin{array}{l}\text { - } \quad \text { Tingkat peran sebagai Pembina } \\
\text { - } \quad \text { Mentensitas pengarah } \\
\text { tentang kurikun surat keputusan dan pembelajaran } \\
\text { - } \\
\text { - Adanya dukungan dan } \\
\text { - } \\
\text { Adanya dukungan sarana dukungan prasarana untuk } \\
\text { kelancaran kegiatan }\end{array}$ \\
\hline & LPMP & $\begin{array}{l}\text { - Intensitas sebagai lembaga yeng } \\
\text { memberikan pendampingan dalam } \\
\text { pengembangan kurikulum dan } \\
\text { pembelajaran yan sinergis } \\
\end{array}$ \\
\hline & PPPG & $\begin{array}{l}\text { - Intensitas sebagai lembaga yang } \\
\text { memberikan pendampingan dalam } \\
\text { pengembangan kurikulum dan } \\
\text { pembelajaran yang sinergis } \\
\end{array}$ \\
\hline & Perguruan Tinggi & $\begin{array}{l}\text { - Intensitas membina kurikulum dan } \\
\text { pembelajaran } \\
\text { - Kedekatan sebagai mitra kerja dalam } \\
\text { melaksankan peran dan tugas } \\
\text { pembinaan kurikulum dan } \\
\text { pembelajaran } \\
\end{array}$ \\
\hline & $\begin{array}{l}\text { Dewan } \\
\text { Pendidikan }\end{array}$ & $\begin{array}{ll}\text { - } & \text { Intensitas mitra dalam } \\
\text { pengembangan kurikulum dan } \\
\text { pembelajaran } \\
\text { - } \\
\text { - } \\
\text { Kemauan menampung informasi } \\
\text { serta aspirasi masyarakat terkait } \\
\text { dengan kurikulum dan pembelajaran } \\
\end{array}$ \\
\hline & Komite Sekolah & $\begin{array}{l}\text { Kedekatan mitra sekolah dalam } \\
\text { pengembangan kurikulum dan }\end{array}$ \\
\hline
\end{tabular}




\begin{tabular}{|c|c|c|}
\hline & & \begin{tabular}{|l} 
pembelajaran \\
Frekuensi komite sekolah \\
mengidentifikasi kebutuhan dan \\
keunggulan lokal \\
- Kemauan mengakomodasi \\
kebutuhan untuk pengembangan \\
kurikulum dan pembelajaran \\
- Kemauan mengakomodasi \\
keunggulan lokal untuk \\
pengembangan kurikulum dan \\
pembelajaran \\
\end{tabular} \\
\hline & MKKS & $\begin{array}{ll}\text { - Intensitas mitra dalam } \\
\text { pengembangan kurikulum dan } \\
\text { pembelajaran }\end{array}$ \\
\hline & MGMP & $\begin{array}{l}\text { - Intensitas mitra dalam } \\
\text { pengembangan kurikulum dan } \\
\text { pembelajaran }\end{array}$ \\
\hline & Organisasi Profesi & 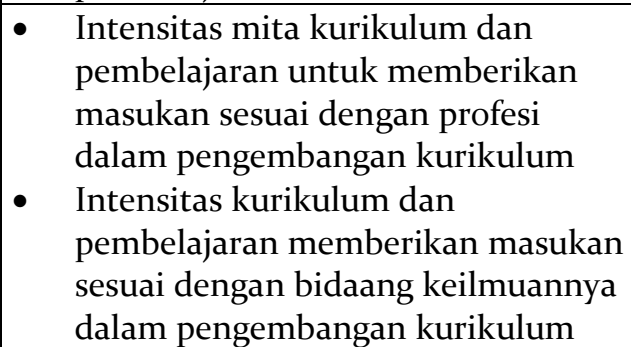 \\
\hline Program Kerja & $\begin{array}{l}\text { Peningkatan } \\
\text { Kemampuan }\end{array}$ & 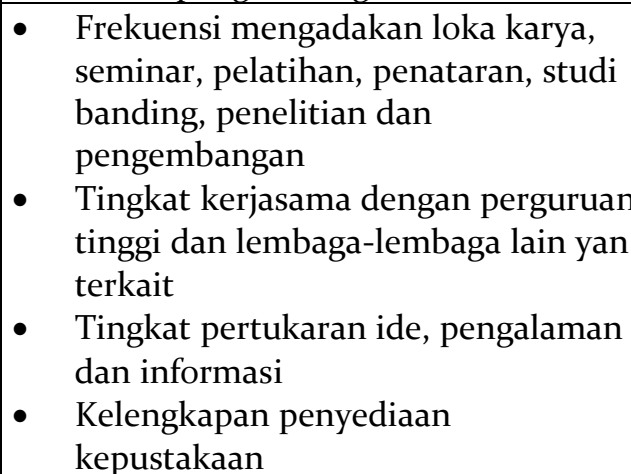 \\
\hline & $\begin{array}{l}\text { Pendampingan } \\
\text { Pengembangan } \\
\text { Kurikulum }\end{array}$ & $\begin{array}{ll}\text { - } & \text { Terkajinya dokumen kebijakan } \\
\text { nasional dan daerah } \\
\text { - }\end{array}$ \\
\hline
\end{tabular}




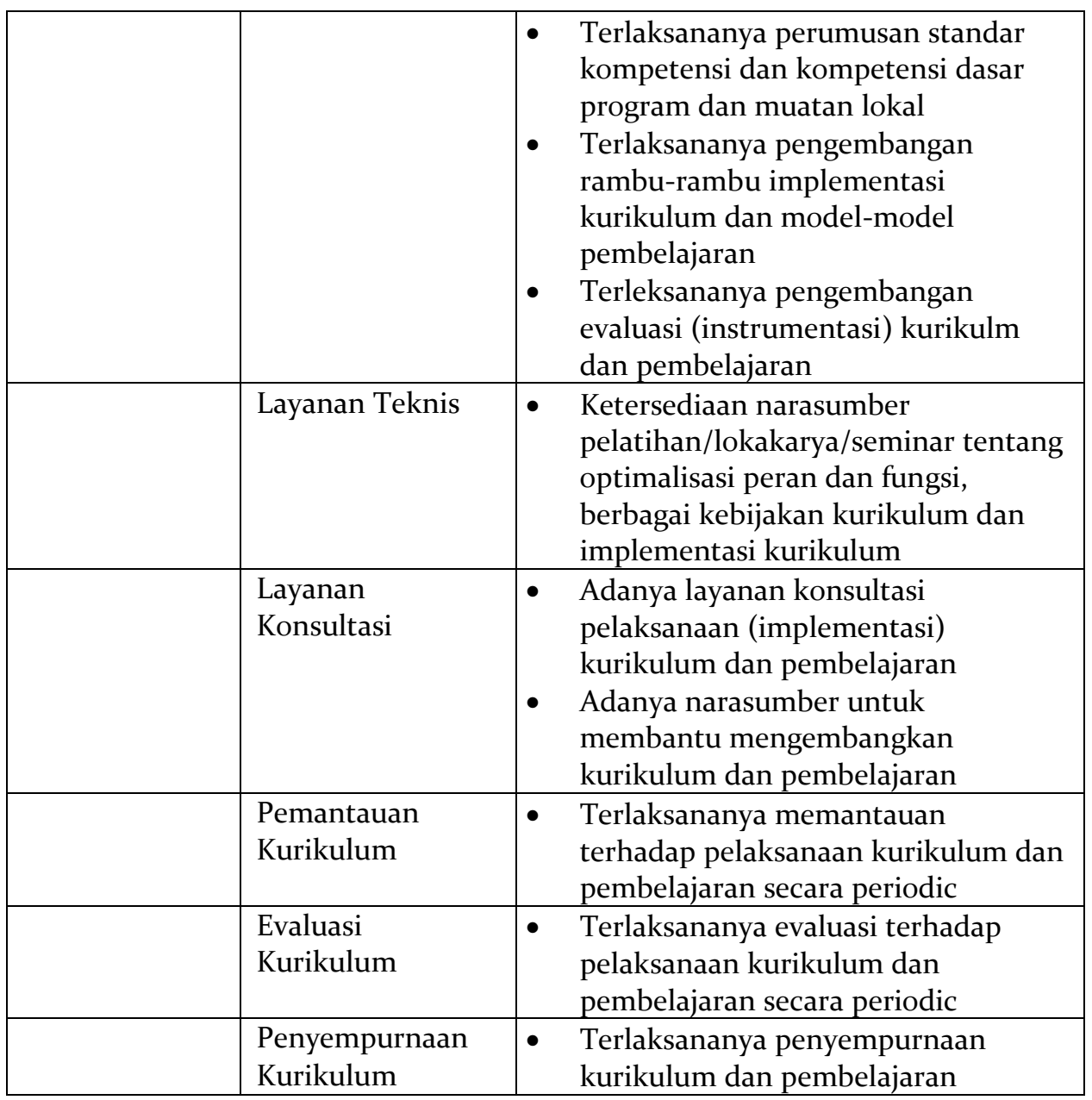

\section{Manajemen Evaluasi Kurikulum dan Pembelajaran}

1. Evaluasi Kurikulum

Permendikbud Nomor 159 tahun 2014 menjelaskan bahwa evaluasi kurikulum adalah serangkaian kegiatan terencana, sistematis, dan sistematik dalam mengumpulkan dan mengolah informasi, memberikan pertimbangan dalam pengambilan keputusan untuk menyempurnakan kurikulum. Evaluasi kurikulum dilakukan melalui pendekatan, strategi dan 
model evaluasi kurikulum sesuai dengan tujuan dan atau sasaran evaluasi. ${ }^{24}$

Pendekatan kurikulum merupakan cara pandang dalam mengevaluasi kurikulum, yang dilakukan dengan menggunakan pendekatan kualitatis dan atau kuantitatif. Strategi evaluasi kurikulum dilakukan secara deduktif atau induktif dengan langkah-langkah yang sistematik dan sistemik yang digunakan untuk mendapatkan data dan informasi yang akurat dan valid. Sedangkan model evaluasi kurikulum merupakan kerangka konseptual dan operasional yang dibunakan untuk mengevaluasi perangkat, dokumen, buku, pelatihan, pendampingan dan monitoring untuk kelancaran pelaksanaan pembelajaran.

Evaluasi kurikulum dilakukan terhadap pengembangan dokumen kurikulum, implementasi kurikulum, hasil kurikulum, dan dampak kurikulum, berikut penjelasannya:

a. Pengembangan dokumen kurikulum dilakukan untuk mendapatkan informasi mengenai kesesuian antara substansi dokumen kurikulum dan desain kurikulum

b. Evaluasi implementasi kurikulum dilakukan untuk mendapatkan informasi mengenai kesesuaian antara implementasi kurikulum dan dokumen kurikulum

c. Evaluasi terhadap hasil kurikulum dilakukan untuk mendapatkan informasi mengenai kesesuaian antara capaian pembelajaran dengan kompetensi inti dan standar kompetensi lulusan

d. Evaluasi dampak kurikulum dilakukan untuk mendapatkan informasi mengenai implikasi perolehan kompetensi sikap, pengetahuan dan keterampilan peserta didik terhadap perubahan sikap perilaku kolektif masyarakat di sekitarnya. ${ }^{25}$

\footnotetext{
${ }^{24}$ Permendikbud Nomor 159 Tahun 2014 tentang Evaluasi Kurikulum.

${ }^{25}$ Teguh Triwiyanto, Manajemen Kurikulum dan Pembelajaran, (Jakarta:
}

Bumi Aksara, 2013). 19 
2. Evaluasi Pembelajaran

Evaluasi atau penilaian adalah proses sistematis, meliputi mengumpulan informasi (angka, deskripsi dan verbal), analisis, interpretasi informasi untuk membuat keputusan. Penilaian dibuat oleh (1) pendidik (internal) direncanakan dan dilakukan pendidik saat proses pembelajaran (penjaminan mutu), (2) satuan pendidikan (internal), (3) penilaian pencapaian SKL atau sebagai dasar pertimbangan kelulusan, dilakukan oleh pemerintah (eksternal) sebagai pengendali mutu. ${ }^{26}$

Mekanisme penilaian yang meliputi pengumpulan, pengolahan, dan penggunaan infoemasi (angka atau deskripsi verbal) yang objektif oleh pendidik melalui sejumlah bukti untuk menentukan pencapaian hasil belajar atau kompetensi peserta didik. Penilaian hasil belajar oleh pendidika dilakukan secara berkesinambungan, bertujuan untuk memamntau proses, kemajuan belajar peserta didik, dan untuk meningkatkan efektivitas kegiatan pembelajaran. ${ }^{27}$

Pelaksanaan penilaian dilakukan dan dikembangkan dengan menyediakan sistem pencatatanyang bervariasi. Penilaian yang bervariasi seperti penilaian secara tertulis, lisan, produk, portofolio, unjuk kerja, mini proyek, pengamatan, dan penilaian diri. Selain itu prosedur pelaksanaan penilaian disesuaikan dengan tujuan dan kegiatan pembelajaran. Melalui keterpaduan antara penilaian dan pembelajaran, pelaksanaan penilaian dilakukan sebelum, selama dan setelah pembelajaran. Penilaian yang dilakukan oleh pendidik hendaknya mengacu pada Penilaian Berbasis Kelas (PBK). PBK merupakan proses pengumpulan, pengolahan, dan penggunaan informasi (angka, deskripsi verbal) yang objektif oleh pendidik yang bersangkutan melalui sejumlah bukti untuk menentukan capaian hasil belajar atau kompetensi peserta didik. ${ }^{28}$

\footnotetext{
${ }^{26}$ Ibid

${ }^{27}$ Ibid

${ }^{28}$ Teguh Triwiyanto, Manajemen Kurikulum dan Pembelajaran,
} 


\section{Peran dan Fungsi Manajemen Kurikulum dan Pembelajaran Sebagai Salah Satu Komponen Pendidikan Nasional}

Mutu manejemen kurikulum dan pembelajaran memperlihatkan keterkaitan kurikulum dan pembelajaran sebagai salah satu komponen manajemen pendidikan dengan standar nasional pendidikan. Untuk mencapai lulusan yang baik mutunya diperlukan dukungan dari standar isi, standar proses dan standar kompetensi lulusan. Selain itu standar pendidik dan tenaga kependidikan, standar sarana dan prasarana serta standar pembiayaan juga menjadi pendorong untuk mencapai lulusan yang baik. Keterkaitan tersebut menunjukkan bahwa manajemen kurikulum dan pembelajaran memerlukan strategi untuk mencapai pendidikan yang efektif dan efisien. Strategi tersebut merupakan upaya pendayagunaan sumber daya yang ada dalam sistem pendidikan nasional. Gambar 9 memperlihatkan keterkaitan manajemen kurikulum dan pembelajaran di antara standar nasional pendidikan.

Berdasarkan pasal 37 dan pasal 38 Undang-Undang Nomor 20 Tahun 2003 tentang Sistem Pendidikan Nasional, kurikulum pendidikan dasar dan menengah wajib memuat pendidikan agama, pendidikan kewarganegaraan, bahasa, matematika, ilmu pengetahuan alam, ilmu oengetahuan sosialm seni dan budaya, pendidikan jasmani dan olah raga, keterampilan/kejuruan, dan muatan lokal. Kerangka dasar dan struktur kurikulum pendidikan dasar dan menengah ditetapkan oleh pemerintah. Kurikulum pendidikan dasar dan menengah dikembangkan sesuai dengan relevansinya oleh setiap kelompok atau satua pendidikan dan komite sekolah di bawah kordinasi dan supervisi dinas pendidikan atau kantor kementerian agama kabupaten/kota untuk pendidikan dasar dan provinsi untuk pendidikan menengah. Sementara itu kurikulum pendidiak tinggi wajib mamuat pendidikan agama, pendidikan kewarganegaraan dan bahasa. Kurikulum perguruan tinggi dikembangkan oleh perguruan tinggi yang bersangkutan dengan mengacu pada standar nasional pendidikan untuk setiap program studi. Kerangka dasar dan struktur kurikulum pendidikan tinggi 
JIEMAN: Journal of Islamic Educational Management

yang bersangkutan dengan mengacu pada standar nasional pendidikan untuk setiap program studi.

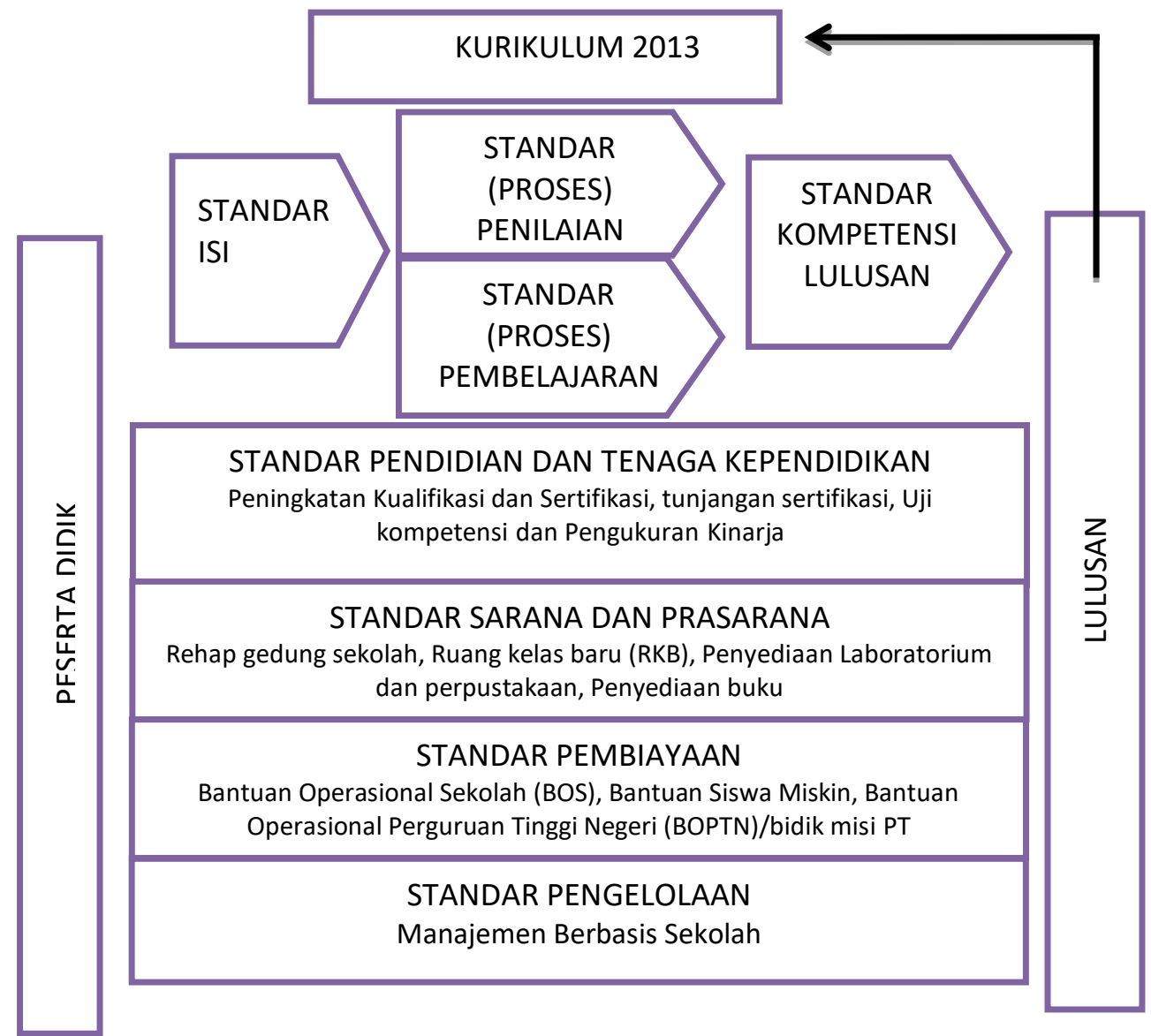

Gambar 9. Manajemen Kurikulum dan Pembelajaran di Antara Standar Pendidikan Nasional pada Kuriklulum ${ }^{29}$

Kurikulum sering dikaitkan dengan mutu pembelajaran, artinya melalui kurikulum yang baik akan menghasilkan mutu pembelajaran yang baik pula sehingga pembelajaran akan berjalan efektif dan efisien. Mutu pembelajaran adalah tingkat keberhasilan

${ }^{29}$ Permendikbud Nomor 159 Tahun 2014 tentang Evaluasi Kurikulum. 
penataan lingkungan yang memberi nuansa agar program belajar tumbuh dan berkembang secara optimal. Guru dalam mengajarkan suatu bidang studi merasa berhasil apabila mampu menyelesaikan semua materi program pembelajaran yang telah dirancangnya sendiri. ${ }^{30}$

Dewasa ini pembelajaran bukan lagi didasarkan pada penuntasan materi, melainkan pada proses dan hasil yang diukur dari kemampuan yang telah dicapai peserta didik baik secara individu maupun rata-rata kelas. Latar inilah yang melahirkan kurikulum 2004 yang dikenal dengan Kurikulum Berbasi Kompetensi (KBK) atau competence based curriculum dan dilanjutkan dengan Kurikulum Tingkat Satuan Pendidiakan (KTSP) tahun 2006, selain itu kurikulum 2013 juga memperlihatkan keberlanjutan penggunaan KBK.

Untuk mencapai keberhasilan pendidikan, terdapat dua komponen yang memengaruhi, yaitu komponen yang berasal dari dalam diri individu yang sedang belajar, dan komponen yang berasal dari luar individu. Komponen yang berasal dari dalam individu dikelompokkan menjadi dua subkomponen, yaitu komponen psikis dan komponen fisik. Kedua subkomponen tersebut keberadaannya ada yang ditentukan oleh faktor keturunan, ada yang ditentukan oleh faktor lingkungan dan ada pula yang ditentukan oleh faktor keturunan dan lingkungan . komponen yang berasal dari luar individu dikelompokkan menjadi subkomponen lingkungan alam, guru, metode mengajar, kurikulum, program, metode pelajaran, sarana dan prasarana serta kondisi sosial ekonomi. ${ }^{31}$

Untuk komponen yang berasal dari luar individu diperlukan manajemen untuk mengarahkan pada tujuan pendidikan. Keberhasilan pengelolaan komponen-komponen tersebut akan

${ }^{30}$ Ulfatin Arifin, Manajemen Pembelajaran di Sekolah Dasar, Strategi Pembelajran Model Belajar Mandiri Berabasis PAKEM, Makalah disampaikan dalam pendidikan dan pelatihan Manajemen Sekolah bagi kepala sekolah dasar se-Indonesia. Malang, Juli-Agustus 2004

${ }^{31}$ Teguh Triwiyanto, Manajemen Kurikulum dan Pembelajaran, 12 
meningkatkan mutu proses dan mutu hasil pendidikan. Kurikulum sebagai komponen yang berasal dari luar individu memerlukan aktivitas manajemen untuk mencapai tujuan pendidikan yang efektif dan efisien.

Perbandingan kurikulum dapat dilihat pada table berikut yang dapat dicermati melalui beberapa aspek, yaitu pengertian, tujuan, latar belakang, prinsip, pengembangan silabus, standar kompetensi lulusan, standar isi, struktur dan muatan kurkulum, serta tata kelola. Perbandingan meliputi kurikulum 1994, 2004, 2006 dan 2013. Khusus kurikulum 2004 dan 2006 dijadikan satu karena kduanya sama, kurikulum 2006 dan KTSP merupakan pelaksanaan kurikulum 2004 pada satuan pendidikan. Perbandingan tersebut untuk memperlihatkan bagaimana karakteristik dari setiap kurikulum memiliki pola dan sistematika sendiri.

Tabel 3. Perbandingan kurikulum 1994, 2004, 2006 dan $2013^{32}$

\begin{tabular}{|c|c|c|c|}
\hline Aspek & Kurikulum 2004 & $\begin{array}{c}\text { Kurikulum } 2004 \\
\text { dan } 2006\end{array}$ & Kurikulum 2013 \\
\hline Pengertian & $\begin{array}{l}\text { Kurikulum } 1994 \\
\text { dibuat sebagai } \\
\text { penyempurnaan } \\
\text { kurikulum } 1984 \text { dan } \\
\text { dilaksanakan sesuai } \\
\text { Undang-Undang } \\
\text { Nomor } 2 \text { Tahun } \\
\text { 1989 tantang Sistem } \\
\text { Pendidikan } \\
\text { Nasional. Hal ini } \\
\text { berdampak pada } \\
\text { sistem pembagian } \\
\text { waktu pelajaran, } \\
\text { yaitu mengubah } \\
\text { dari sistem } \\
\text { semester ke sistem } \\
\text { caturwulan. Dengan }\end{array}$ & $\begin{array}{l}\text { KTSP adalah } \\
\text { kurikulum } \\
\text { operasional yang } \\
\text { disusun oleh dan } \\
\text { dilaksanakan di } \\
\text { masing-masing } \\
\text { satuan pendidikan. } \\
\text { KTSP terdiri atas } \\
\text { tujuan pendidikan } \\
\text { tingkat satuan } \\
\text { pendidikan, } \\
\text { struktur dan } \\
\text { muatan kurikulum } \\
\text { tingkat satuan } \\
\text { pendidikan, } \\
\text { kalender } \\
\text { pendidikan dan }\end{array}$ & $\begin{array}{l}\text { Kurikulum } 2013 \\
\text { merupakan langkah } \\
\text { lanjutan } \\
\text { pengembangan } \\
\text { Kurikulum Berbasis } \\
\text { Kompetensi (KBK) } \\
\text { yang telah dirintis } \\
\text { pada tahun } 2004 \\
\text { dan KTSP 2006 } \\
\text { yang mencakup } \\
\text { kompetensi sikap, } \\
\text { pengetahuan dan } \\
\text { keterampilan secara } \\
\text { individu. }\end{array}$ \\
\hline
\end{tabular}

${ }^{32}$ Pusat Kurikulum, 2007 dan Kemendikbud, 2013 


\begin{tabular}{|c|c|c|c|}
\hline & $\begin{array}{l}\text { sistem caturwulan } \\
\text { yang pembagiannya } \\
\text { dalam satu tahun } \\
\text { menjadi tig tahap, } \\
\text { diharapkan dapat } \\
\text { memberi } \\
\text { kesempatan bagi } \\
\text { siswa untuk dapat } \\
\text { menerima materi } \\
\text { pelajaran cukup } \\
\text { banyak. }\end{array}$ & silabus & \\
\hline Tujuan & $\begin{array}{l}\text { Tujuan kurikulum } \\
\text { 1994 adalah } \\
\text { mempersiapkan } \\
\text { siswa agar sanggup } \\
\text { menghadapi } \\
\text { perubahan keadaan } \\
\text { di dalam kehidupan } \\
\text { ddan di dunia yang } \\
\text { selalu berkembang } \\
\text { melalui latihan } \\
\text { bertindak atas dasar } \\
\text { pemikiran secara } \\
\text { logis, rasional, } \\
\text { kritis, jujur, cermat, } \\
\text { efektif, dan efisien. } \\
\text { Salah satu kegiatan } \\
\text { yang } \\
\text { memungkinkan } \\
\text { agar kegiatan } \\
\text { tersebut tercapai } \\
\text { adalah siswa } \\
\text { diharapkan mau } \\
\text { mengikuti ajang } \\
\text { kompetensi dalam } \\
\text { bidang matematika, } \\
\text { baik di dalam kota } \\
\text { maupun di luar } \\
\text { kota, bahkan } \\
\text { memungkinkan } \\
\text { siswa diikutsertakan } \\
\text { dalam ajang }\end{array}$ & $\begin{array}{l}\text { Tujuan yang ingin } \\
\text { dicapai kurikulum } \\
\text { 2oo4 menekankan } \\
\text { pada capaian } \\
\text { kompetensi siswa } \\
\text { baik secara } \\
\text { individual dan } \\
\text { klasikal } \\
\text { Tujuan kurikulum } \\
\text { 2oo6 disesuaikan } \\
\text { dengan satuan } \\
\text { pendidikan. Tujuan } \\
\text { pendidikan tingkat } \\
\text { satuan pendidikan } \\
\text { dasar dan } \\
\text { menengah } \\
\text { dirumuskan } \\
\text { mengacu pada } \\
\text { tujuan umum } \\
\text { pendidikan } \\
\text { tersebut: } \\
\text { Tujuan } \\
\text { pendidikan } \\
\text { dasar adalah } \\
\text { meletakkan } \\
\text { dasar } \\
\text { keserdasan, } \\
\text { pengetahuan, } \\
\text { kepribadian, } \\
\text { akhlak mulia } \\
\text { serta }\end{array}$ & $\begin{array}{l}\text { Kurikulum } 2013 \\
\text { bertujuan untuk } \\
\text { mempersiapkan } \\
\text { manusia Indonesia } \\
\text { agar memiliki } \\
\text { kemampuan hidup } \\
\text { sebagai pribadi dan } \\
\text { warga Negara yang } \\
\text { beriman, produktif, } \\
\text { kreatif, inovatif dan } \\
\text { efektif serta mampu } \\
\text { berkontribusi pada } \\
\text { kehidupan } \\
\text { bermasyarakat, } \\
\text { berbangsa, } \\
\text { bernegara dan } \\
\text { peradaban dunia. }\end{array}$ \\
\hline
\end{tabular}


JIEMAN: Journal of Islamic Educational Management

\begin{tabular}{|c|c|c|c|}
\hline & $\begin{array}{l}\text { kompetisi luar } \\
\text { negeri. } \\
\text { Tujuan pengajaran } \\
\text { menekankan pada } \\
\text { pemahaman konsep } \\
\text { dan keterampilan } \\
\text { menyelesaikan soal } \\
\text { dan pemecahan } \\
\text { masalah. }\end{array}$ & \begin{tabular}{|l} 
keterampilan \\
untuk hidup \\
mandiri dan \\
mengikuti \\
pendidikan lebih \\
lanjut. \\
2. \\
pujuan \\
pendidikan \\
menengan \\
adalah \\
meningkatan \\
kecerdasan, \\
pengetahuan, \\
kepribadian, \\
akhlak mulia, \\
serta \\
keterampilan \\
untuk hidup \\
mandiri dan \\
mengikuti \\
pendidikan lebih \\
lanjut \\
Tujuan \\
pendidikan \\
menengah \\
kejuruan adalah \\
meningkatkan \\
kecerdasan, \\
pengetahuan, \\
kepribadian, \\
akhlak mulia \\
serta \\
keterampilan \\
untuk hidup \\
mandiri dan \\
mengikuti \\
pendidikan lebih \\
lanjut sesuai \\
dengan \\
kejurauannya.
\end{tabular} & \\
\hline $\begin{array}{l}\text { Latar } \\
\text { belakang }\end{array}$ & $\begin{array}{l}\text { Kurukulum ini } \\
\text { merupakan }\end{array}$ & $\begin{array}{l}\text { Kurikulum disusun } \\
\text { agar dapat memberi }\end{array}$ & $\begin{array}{l}\text { Latar belakangnya } \\
\text { antara lain: }\end{array}$ \\
\hline
\end{tabular}




\begin{tabular}{|c|c|c|c|}
\hline & $\begin{array}{l}\text { pengembangan dari } \\
\text { kurikulum } \\
\text { sebelumnya dengan } \\
\text { dasar kurikulum } \\
\text { 1984, pada } \\
\text { kurikulum } 1994 \\
\text { muncul istilah } \\
\text { CBSA (cara belajra } \\
\text { siswa aktif). } \\
\text { Kegiatan belajar } \\
\text { cenderung di dalam } \\
\text { kelas, mengejar } \\
\text { target maateri yang } \\
\text { harus dikuasai, } \\
\text { berorientasi } \\
\text { kognitif. } \\
\text { Dilaksanakan sesuai } \\
\text { dengan Undang- } \\
\text { Undang Nomor } 2 \\
\text { Tahu 1989 tentang } \\
\text { sistem pendidikan } \\
\text { nasional }\end{array}$ & \begin{tabular}{|ll} 
kesempatan \\
peserta didik untuk \\
1. & Belajar beriman \\
& dan bertakwa \\
& kepada Tuhan \\
& Yang Maha Esa \\
2. & Belajar untuk \\
& memahami dan \\
& menghayati \\
3. & Belajar untuk \\
mampu \\
melaksanakan \\
dan berbuat \\
secara efektif \\
Belajar untuk \\
hidup bersama \\
dan berguna \\
untuk oranglain, \\
dan \\
Belajar untuk \\
membangun dan \\
menemukan jati \\
diri melalui \\
proses belajar \\
yang aktif, \\
kreatif efetif dan \\
menyenangkan
\end{tabular} & $\begin{array}{ll}\text { 1. } & \begin{array}{l}\text { Kompetensi } \\
\text { masa depan }\end{array} \\
\text { 2. } & \begin{array}{l}\text { Persepsi } \\
\text { masyarakat }\end{array} \\
\text { 3. } & \begin{array}{l}\text { Perkembangan } \\
\text { pengetahuan } \\
\text { dan pedagogi, } \\
\text { dan }\end{array} \\
\text { 4. } & \begin{array}{l}\text { Fenomena } \\
\text { negative yang } \\
\text { mengemuka }\end{array}\end{array}$ \\
\hline Prinsip & $\begin{array}{l}\text { Karakteristik } \\
\text { Kurikulum } 1994 \\
\text { yang disebut juga } \\
\text { kurikulum cara } \\
\text { belajar siswa aktif } \\
\text { (CBSA) antara lain: } \\
\text { 1. } \quad \text { Keterlibatan } \\
\text { intelektual, } \\
\text { emosional } \\
\text { siswa dalam } \\
\text { proses belajar } \\
\text { mengajar } \\
\text { Terjadi } \\
\text { asimilasi dan } \\
\text { akomodasi }\end{array}$ & $\begin{array}{l}\text { Prinsip-prinsip } \\
\text { KTSP antara lain: } \\
\text { 1. } \quad \text { Berpusat pada } \\
\text { potensi, } \\
\text { perkembangan } \\
\text { kebutuhan, dan } \\
\text { kepentingan } \\
\text { peserta didik, } \\
\text { serta } \\
\text { lingkungannya. } \\
\text { Beragam dan } \\
\text { terpadu } \\
\text { Tanggap } \\
\text { terhadap } \\
\text { perkembangan }\end{array}$ & $\begin{array}{l}\text { Kurikulum } 2013 \\
\text { dirangcang dengan } \\
\text { karakteristik } \\
\text { berikut: } \\
\text { 1. } \text { Mengembanga } \\
\text { kan } \\
\text { keseimbangan } \\
\text { antara sikap } \\
\text { spiritual dan } \\
\text { sosial, rasa } \\
\text { ingin tahu, } \\
\text { kreativitas, } \\
\text { kerjasama } \\
\text { dengan } \\
\text { kemampuan }\end{array}$ \\
\hline
\end{tabular}




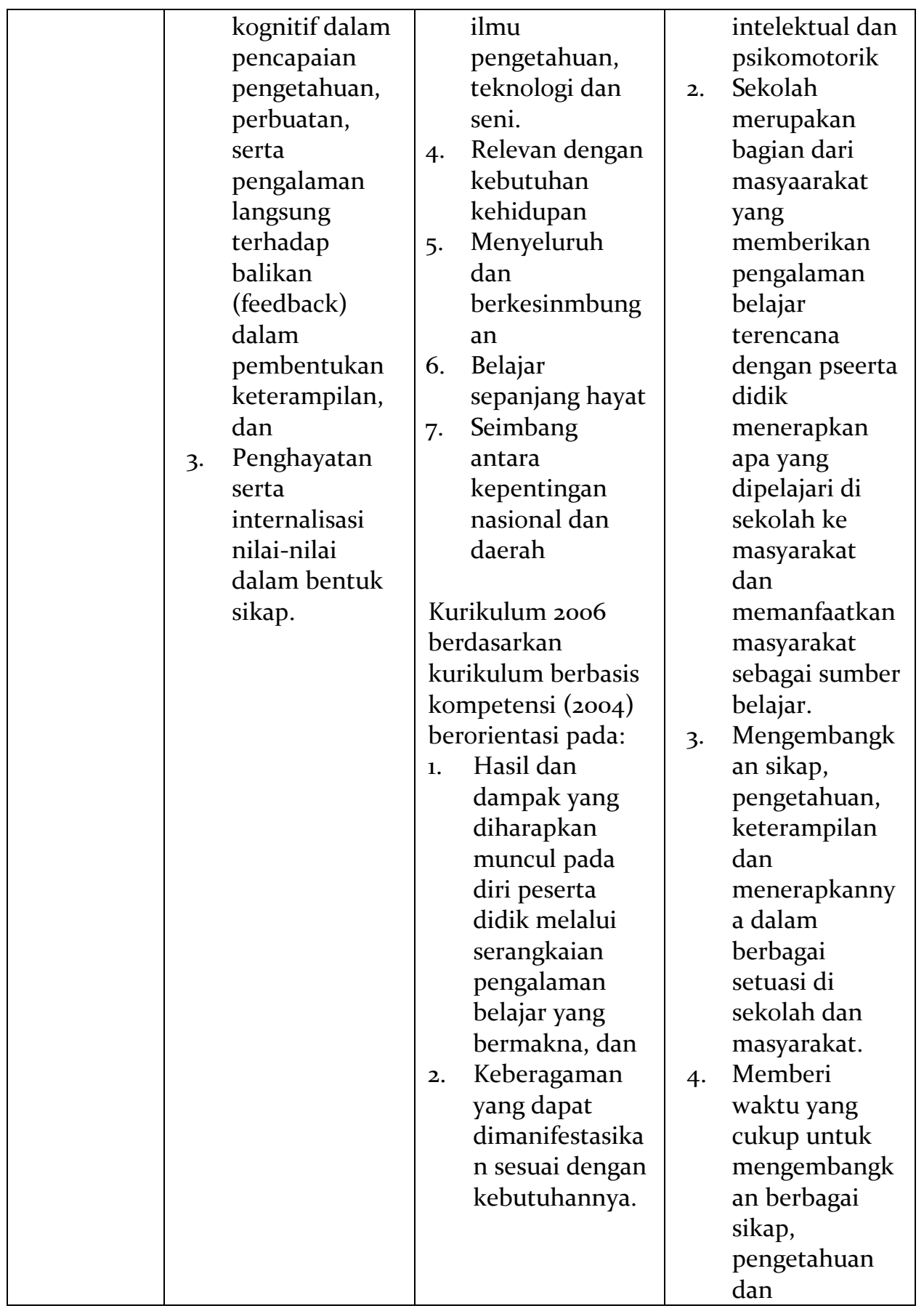




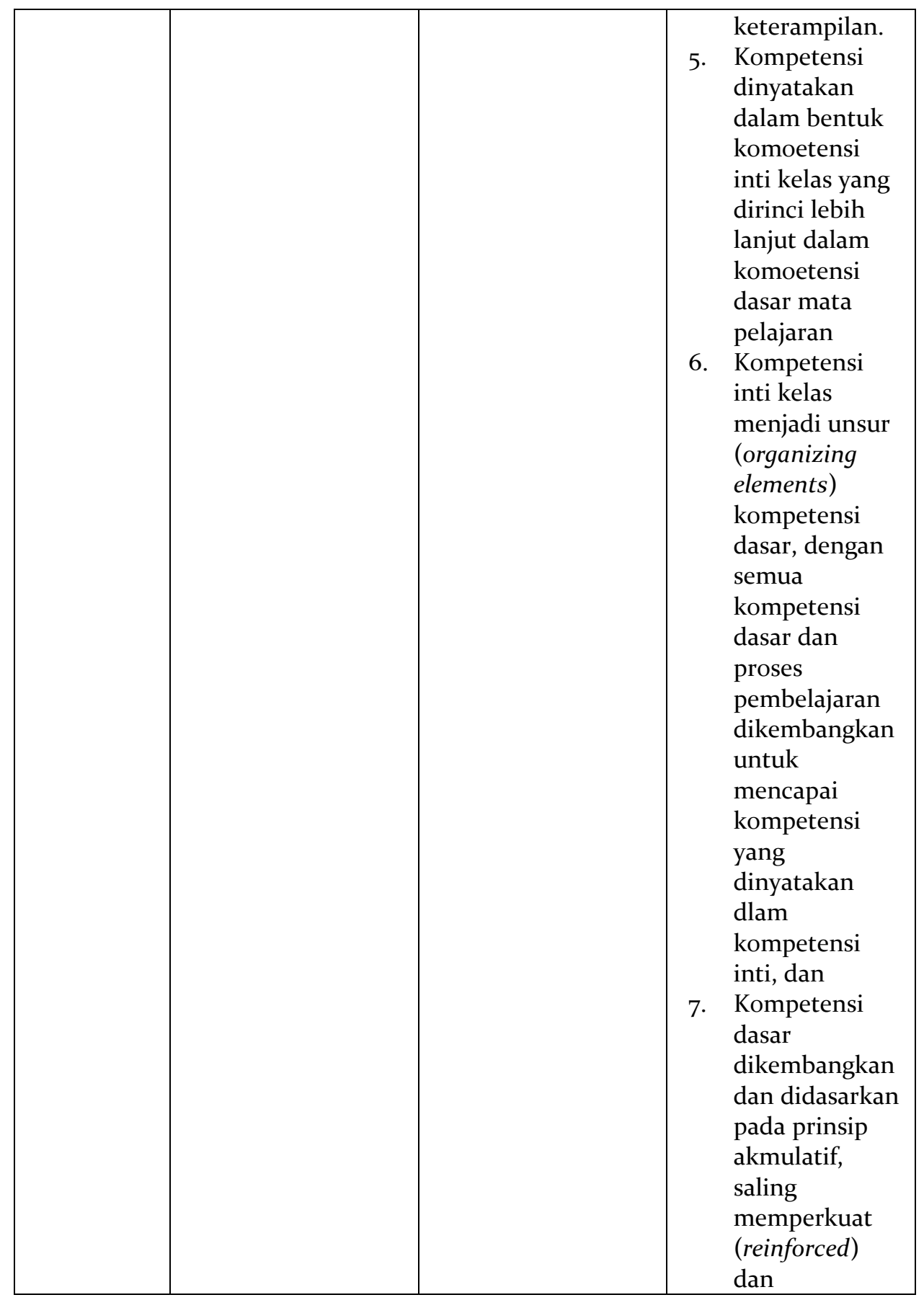




\begin{tabular}{|c|c|c|c|}
\hline & & & $\begin{array}{l}\text { memperkaya } \\
\text { (enriched) } \\
\text { antar mata } \\
\text { pelajaran dan } \\
\text { jenjang } \\
\text { pendidikan } \\
\text { (organisasi } \\
\text { horizontal dan } \\
\text { vertikal). }\end{array}$ \\
\hline $\begin{array}{l}\text { Pengemban } \\
\text { gan Silabus }\end{array}$ & $\begin{array}{l}\text { Kurikulum } 1994 \\
\text { menggunakan asas } \\
\text { kebermaknaan, } \\
\text { berorientasi pada } \\
\text { materi, posisi } \\
\text { sentral berada di } \\
\text { departemen, guru } \\
\text { dan sekolah hanya } \\
\text { melaksanakan } \\
\text { kurikukum dan } \\
\text { silabus ditentukan } \\
\text { oleh pihak } \\
\text { Departemen } \\
\text { Pendidikan } \\
\text { Nasional }\end{array}$ & $\begin{array}{ll}\text { Silabus } \\
\text { dikembangkan } \\
\text { untuk menjawab } \\
\text { pertanyaan : } \\
\text { 1. } & \text { Apa kompetensi } \\
& \text { yang harus } \\
& \text { dikuasai siswa } \\
\text { 2. } & \text { Bagaimana cara } \\
& \text { mencapainya } \\
\text { 3. } & \text { Bagaimana cara } \\
& \text { mengeyahui } \\
& \text { pencapaiannya }\end{array}$ & $\begin{array}{l}\text { Silabus } \\
\text { dikembangkan } \\
\text { berdasarkan } \\
\text { kompetensi lulusan } \\
\text { dan standar isi } \\
\text { untuk satuan } \\
\text { pendidikan dasar } \\
\text { dan menengah } \\
\text { sesuai dengan pola } \\
\text { pembelajaran pada } \\
\text { setiap tahun ajaran } \\
\text { tertentu. Silabus } \\
\text { digunakan sebagi } \\
\text { acuan dalam } \\
\text { pengembangan } \\
\text { rencana } \\
\text { pelaksanaan } \\
\text { pembelajaran. }\end{array}$ \\
\hline $\begin{array}{l}\text { Standar } \\
\text { Kompetens } \\
\text { i Lulusan } \\
\text { (SKL) }\end{array}$ & $\begin{array}{l}\text { Kurikulum } 1994 \\
\text { bersifat populis, } \\
\text { yaitu } \\
\text { memberlakukan } \\
\text { sistem kurikulum } \\
\text { untuk semua siswa } \\
\text { di seluruh } \\
\text { Indonesia. } \\
\text { Kurikulum ini } \\
\text { bersifat kurikulum } \\
\text { inti sehingga daerah } \\
\text { yang khusus dapat } \\
\text { mengembangkan } \\
\text { pengejaran sendiri } \\
\text { disesuaikan dengan }\end{array}$ & $\begin{array}{l}\text { SKL diturunkan dari } \\
\text { standar isi, model } \\
\text { pendidikam disusun } \\
\text { sendiri berdasarkan } \\
\text { kondisi sekolah, } \\
\text { penyusunan SKL } \\
\text { yang dikembangkan } \\
\text { sesuai dengan } \\
\text { kondisi sekolah, } \\
\text { kompetensi/ } \\
\text { karakteristik } \\
\text { daerah, sosial } \\
\text { budaya masyarakat } \\
\text { setempat dan } \\
\text { peserta didik. }\end{array}$ & $\begin{array}{l}\text { SKL diturunkan dari } \\
\text { kebutuhan. SKL } \\
\text { adalah kriteria } \\
\text { mengenai } \\
\text { kualifikasi } \\
\text { kemampuan lulusan } \\
\text { yang mencakup } \\
\text { sikap,pengetahuan } \\
\text { dan keterampilan. } \\
\text { SKL pendidikan } \\
\text { dasar dan } \\
\text { menengah } \\
\text { digunakan sebagai } \\
\text { acuan utama } \\
\text { pengembangan }\end{array}$ \\
\hline
\end{tabular}




\begin{tabular}{|c|c|c|c|}
\hline & $\begin{array}{l}\text { lingkungan dan } \\
\text { kebutuhan } \\
\text { masyarakat sekitar }\end{array}$ & & $\begin{array}{l}\text { standar isi, standar } \\
\text { proses, standar } \\
\text { penilaian } \\
\text { pendidikan, standar } \\
\text { pendidik dan } \\
\text { tenaga } \\
\text { kependidikan, } \\
\text { standar sarana dan } \\
\text { prasarana, standar } \\
\text { pengelolaan dan } \\
\text { standar } \\
\text { pembiayaan. }\end{array}$ \\
\hline Standaar isi & $\begin{array}{l}\text { Guru diperbolehkan } \\
\text { mengubah } \\
\text { sistematika mata } \\
\text { pelajaran, asalkan } \\
\text { dalam satu } \\
\text { caturwulan }\end{array}$ & $\begin{array}{l}\text { Standar isi } \\
\text { dirumuskan } \\
\text { berdasarkan tujuan } \\
\text { mata pelajaran (SKL } \\
\text { mata pelajaran) } \\
\text { yang dirinci } \\
\text { menjadi standar } \\
\text { kompetensi dan } \\
\text { kompetensi dasar } \\
\text { mata pelajaran. } \\
\text { Pemisahan antara } \\
\text { mata pelajaran } \\
\text { pembentuk sikap, } \\
\text { pembentuk } \\
\text { keterampilan dan } \\
\text { pembentuk } \\
\text { pengetahuan. } \\
\text { Kompetensi } \\
\text { diturunkan dari } \\
\text { mata pelajaran. } \\
\text { Mata pelajaran } \\
\text { lepas satu dengan } \\
\text { yang lain, seperti } \\
\text { sekumpulan mata } \\
\text { pelajaran terpisah }\end{array}$ & $\begin{array}{l}\text { Standar isi } \\
\text { diturunkan dari } \\
\text { standar kompetensi } \\
\text { lulusan melalui } \\
\text { kompetensi inti } \\
\text { yang berbasis mata } \\
\text { pelajaran. Semua } \\
\text { mata pelajaran } \\
\text { harus berkontribusi } \\
\text { terhadap } \\
\text { pembentukan sikap, } \\
\text { keterampilan, dan } \\
\text { pengetahuan. Mata } \\
\text { pelajaran } \\
\text { diturunkan dari } \\
\text { kompetensi yang } \\
\text { ingin dicapai. Setiap } \\
\text { mata pelajran diikat } \\
\text { oleh kompetensi } \\
\text { inti (tiap kelas) }\end{array}$ \\
\hline $\begin{array}{l}\text { Struktur } \\
\text { dan } \\
\text { Muatan } \\
\text { Kurikulum }\end{array}$ & $\begin{array}{l}\text { Struktur horizontal } \\
\text { termasuk ke dalam } \\
\text { se-parated subject } \\
\text { (terpisah). Struktul } \\
\text { vertical adalah }\end{array}$ & $\begin{array}{l}\text { Kedalaman muatan } \\
\text { kurikulum } \\
\text { dituangkan dalam } \\
\text { kompetensi yang } \\
\text { harus dikuasai siswa }\end{array}$ & $\begin{array}{l}\text { Struktur kurikulum } \\
\text { terdiri atas } \\
\text { kompetensi inti } \\
\text { dirancang seiring } \\
\text { dengan }\end{array}$ \\
\hline
\end{tabular}




\begin{tabular}{|c|c|c|c|}
\hline & $\begin{array}{l}\text { pelaksanaan } \\
\text { kurikulum di } \\
\text { sekolah yang } \\
\text { merupakan sistem } \\
\text { caturwulan. Sistem } \\
\text { caturwulan } \\
\text { membagi waktu } \\
\text { belajar satu tahun } \\
\text { ajaran menjadi tiga } \\
\text { bagian waktu (1 } \\
\text { tahun = } 3 \\
\text { caturwulan), sistem } \\
\text { caturwulan 1,2, dan } \\
\text { 3. Caturwulan } 1 \text { dan } \\
2 \text { (12 minggu) untuk } \\
\text { kelas } 12 \text { dan 3, dan } \\
\text { caturwulan } 1 \text { dan } 2 \\
\text { (10 minggu efektif) } \\
\text { untuk kelas } 3 \text { (8 } \\
\text { minggu efektif). } \\
\text { Waktu bidang studi } \\
48 \text { jam (1 } \\
\text { caturwulan) }\end{array}$ & $\begin{array}{l}\text { dengan beban } \\
\text { belajar yang } \\
\text { tercantum dalam } \\
\text { struktur kurikulum, } \\
\text { merupakan pola } \\
\text { dan susunan mata } \\
\text { pelajaran yang } \\
\text { harus ditempuh } \\
\text { oleh siswa dalam } \\
\text { kegiatan } \\
\text { pembelajaran. } \\
\text { Kompetensi terdiri } \\
\text { atas Standar } \\
\text { Kompetensi (SK) } \\
\text { dan Kompetensi } \\
\text { Dasar (KD) yang } \\
\text { dikembangkan } \\
\text { berdasarkan } \\
\text { Standar Kompetensi } \\
\text { Lulusan (SKL). } \\
\text { Muatan lokal dan } \\
\text { pengembangan diri } \\
\text { merupakan bagian } \\
\text { integral dari } \\
\text { struktur kurikulum } \\
\text { sekolah. }\end{array}$ & $\begin{array}{l}\text { meningkatnya usia } \\
\text { peserta didik pada } \\
\text { kelas tertentu. } \\
\text { Melalui kompetensi } \\
\text { inti, integrasi } \\
\text { vertikal berbagai } \\
\text { kompetensi dasar } \\
\text { pada kelas yang } \\
\text { berbeda dapat } \\
\text { dijaga. } \\
\text { Rumusan } \\
\text { kompetensi inti } \\
\text { menggunakan } \\
\text { notasi berikut : } \\
\text { 1. Kompetensi } \\
\text { Inti-1 (KI-1) } \\
\text { untuk } \\
\text { kompetensi inti } \\
\text { sikap spiritual } \\
\text { 2. Kompetensi } \\
\text { Inti-2 (KI-2) } \\
\text { untuk } \\
\text { kompetensi inti } \\
\text { sikap sosial } \\
\text { 3. Kompetensi } \\
\text { Inti-3 (KI-3) } \\
\text { untuk } \\
\text { kompetensi inti } \\
\text { pengetahuan, } \\
\text { dan } \\
\text { 4. Kompetensi } \\
\text { Inti-4 (KI-4) } \\
\text { untuk } \\
\text { kompetensi inti } \\
\text { keterampilan. }\end{array}$ \\
\hline Tata Kelola & $\begin{array}{l}\text { Acuan norma dan } \\
\text { tes objektif, } \\
\text { penyampaian } \\
\text { materi oleh guru, } \\
\text { teaching: berpusat } \\
\text { pada guru, metode } \\
\text { ceramah, guru }\end{array}$ & $\begin{array}{l}\text { Sekolah } \\
\text { menyelenggarakan } \\
\text { pendidikan dengan } \\
\text { sistem paket atau } \\
\text { SKS. Sistem paket } \\
\text { adalah sistem } \\
\text { penyelenggaraan }\end{array}$ & $\begin{array}{lr}\begin{array}{l}\text { Kurikulum } \\
\text { dilakukan } \\
\text { kelola }\end{array} & \begin{array}{r}2013 \\
\text { tata } \\
\text { berikut: }\end{array} \\
\text { sebagai } \\
\text { 1. } \begin{array}{l}\text { Tata } \\
\text { pendidik }\end{array} & \text { kerja } \\
\text { bersifat } & \\
\end{array}$ \\
\hline
\end{tabular}




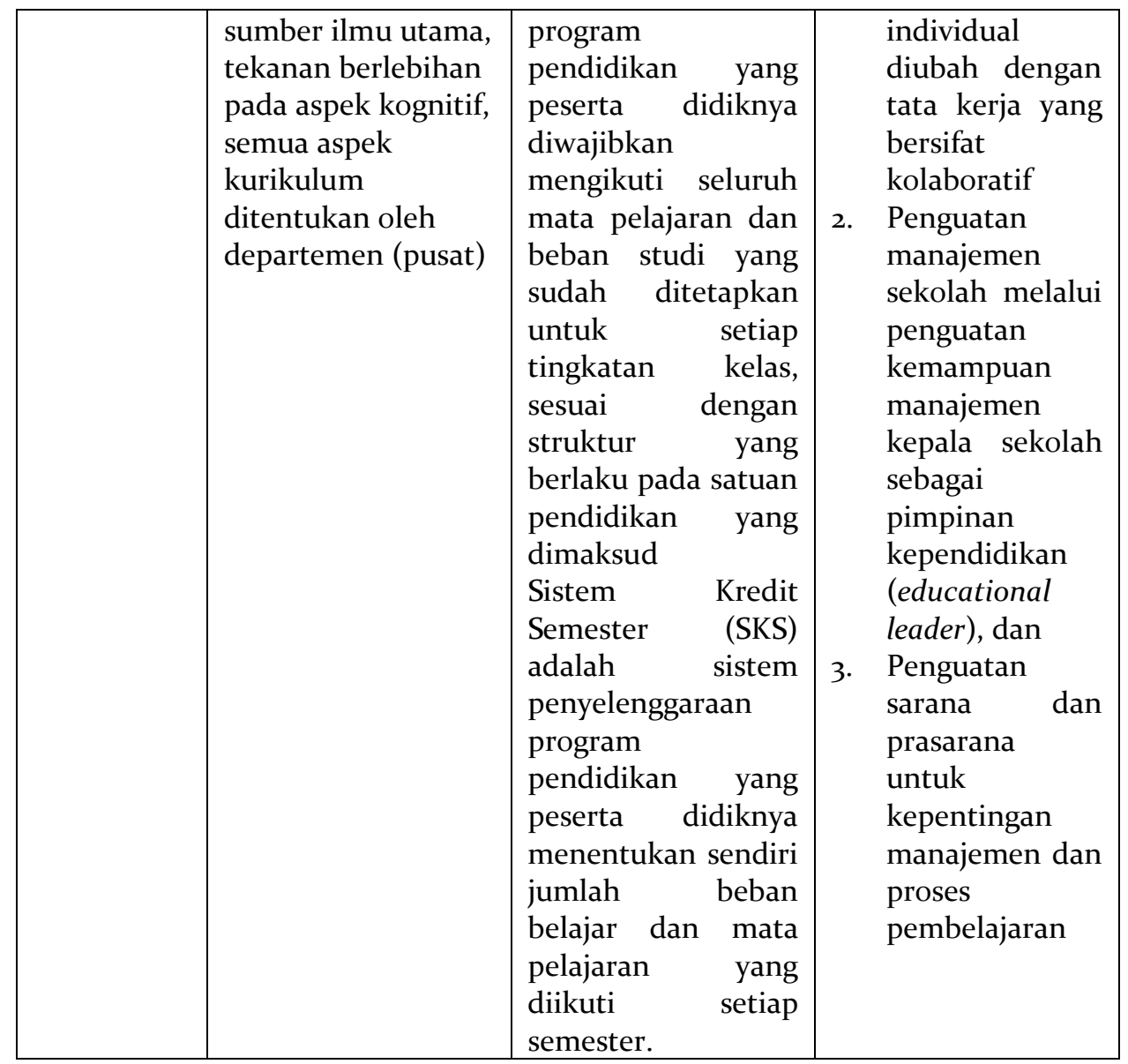

\section{Simpulan}

Manajemen kurikulum dan pembelajaran dalam sistem pendidikan nasional merupakan suatu proses yang sangat komplek dan melibatkan berbagai komponen yang saling terkait dalam rangka mengarahkan segala bentuk aktivitas pendidikan untuk mencapai tujuan pendidikan nasional. Prosedur manajemen kurikulum dan pembe-lajaran antara lain: (1) Perencanaan Manajemen Kurikulum dan pembelajaran yaitu menentukan sasaran, tujuan, strategi dan fungsi yang hendak dicapai, (2) Pengorganisasian Kurikulum dan Pembelajaran yaitu perpaduan antara dua kurikulum atau lebih sehingga menjadi satu kesatuan 
yang utuh dan diharapkan dapat menggairahkan proses pembelajaran menjadi lebih bermakna, (3) Pelaksanaan Manajemen Kurikulum dan Pembelajaran yaitu proses penerapan ide, konsep, kebijakan dan inovasi dalam bentuk tindakan praktis sehingga memberikan dampak baik berupa perubahan, pengetahuan, keterampilan, maupun nilai dan sikap, (4) Evaluasi Manajemen Kurikulum dan pembelajaran merupakan tindakan penilaian, penjaminan dan penetapan mutu manajemen kurikulum dan pembelajaran berdasarkan pertimbangan dan kriteria tertentu dalam rangka menentukan keefektifan manajemen kurikulum dan pembelajaran.

\section{Referensi}

Arifin, Ulfatin. Manajemen Pembelajaran di Sekolah Dasar, Strategi Pembelajran Model Belajar Mandiri Berbasis PAKEM, Makalah disampaikan dalam pendidikan dan pelatihan Manajemen Sekolah bagi kepala sekolah dasar se-Indonesia, Malang Juli-Agustus 2004

Arikunto, Suharsimi dan L Yuliana. Manajemen Pendidikan, Yogyakarta: Aditya Media, 2010.

Hamalik, Oemar, Dasar-dasar Pengembangan Kurikulum, Bandung: Remaja Rosdakarya, 2007.

Hidayat, Sholeh, Pengembangan Kurikulum Baru. Bandung: Remaja Rosdakarya, 2013.

Ibrahim, Nasbi. Manajemen Kurikulum Sebuah Kajian Teoritis. Jurnal Idaroh. Vol 1 No 2017.

Kementerian Pendidikan Nasional. Manajemen Berbasis Sekolah. Jakarta: Pusat Pengembangan Tenaga Kepenendidikan, 2011.

Peraturan Menteri Pendidikan dan Kebudayaan Nomor 159 Tahun 2014 tentang Evaluasi Kurikulum. 
Peraturan Menteri Pendidikan dan Kebudayaan Nomor 57 Tahun 2014 Tentang Kompetensi Dasar dan Struktur Kurikulum $\mathrm{SD} / \mathrm{MI}$.

Peraturan Menteri Pendidikan dan Kebudayaan Nomor 58 Tahun 2014 Tentang Kompetensi Dasar dan Struktur Kurikulum SMP/MTs.

Peraturan Menteri Pendidikan dan Kebudayaan Nomor 59 Tahun 2014 Tentang Kompetensi Dasar dan Struktur Kurikulum SMA/MA.

Peraturan Menteri Pendidikan dan Kebudayaan Nomor 81 A Tahun 2013 tentang Implementasi Kurikulum.

Peraturan Pemerintah Nomor 32 Tahun 2013 tentang Perubahan Atas Peraturan Pemerintah Nomor 19 Tahun 2005 tentang Standar Nasional Pendidikan.

Pusat Kurikulum. Kurikulum Tingkat Satuan Pendidikan. Jakarta: Departemen Pendidikan Nasional, 2007.

Rusman, Manajemen Kurikulum. Jakarta: Rajawali Pres, 2012.

Sanjaya, Wina. Perencanaan dan Desain Sistem Pembelajaran. Jakarta: Kencana Prenada Media Group, 2008.

Syam, Aldo Redo. Posisi Manajemen Kurikulum dan Pembelajaran dalam Pendidikan. Jurnal Muaddib: Vol 7. 2017. http://www.researchgate.net/publication/318676341.

Triwiyanto, Teguh. Manajemen Kurikulum dan Pembelajaran, Jakarta: Bumi Aksara, 2015.

Undang-Undang Nomor 20 Tahun 2003 tentang Sistem Pendidikan Nasional.

Widyastono, Hery. "Implikasi RPJMN 2010-2014 Sektor Pendidikan terhadap Manajemen Pengembangan Kurikulum Pendidikan Dasar dan Menengah" 2012 terdapat dalam situs 
JIEMAN: Journal of Islamic Educational Management

http://litbang.kemdikbud.go.id/jurnaldukbud/index.php/jpn k/article/view/93/90. 